\title{
IGFBP-3/IGFBP-3 Receptor System as an Anti-Tumor and Anti-Metastatic Signaling in Cancer
}

\author{
Qing Cai ${ }^{1}$, Mikhail Dozmorov ${ }^{1,2}$ and Youngman Oh $^{1, *}$ (i) \\ 1 Department of Pathology, Medical College of Virginia Campus, Virginia Commonwealth University, \\ Richmond, VA 23298, USA; qing.cai@vcuhealth.org (Q.C.); mikhail.dozmorov@vcuhealth.org (M.D.) \\ 2 Department of Biostatistics, Massey Cancer Center, Virginia Commonwealth University, Richmond, \\ VA 23298, USA \\ * Correspondence: youngman.oh@vcuhealth.org; Tel.: +1-804-827-1324
}

Received: 14 April 2020; Accepted: 18 May 2020; Published: 20 May 2020

\begin{abstract}
Insulin-like growth factor binding protein-3 (IGFBP-3) is a p53 tumor suppressor-regulated protein and a major carrier for IGFs in circulation. Among six high-affinity IGFBPs, which are IGFBP-1 through 6, IGFBP-3 is the most extensively investigated IGFBP species with respect to its IGF/IGF-I receptor (IGF-IR)-independent biological actions beyond its endocrine/paracrine/autocrine role in modulating IGF action in cancer. Disruption of IGFBP-3 at transcriptional and post-translational levels has been implicated in the pathophysiology of many different types of cancer including breast, prostate, and lung cancer. Over the past two decades, a wealth of evidence has revealed both tumor suppressing and tumor promoting effects of IGF/IGF-IR-independent actions of IGFBP-3 depending upon cell types, post-translational modifications, and assay methods. However, IGFBP-3's anti-tumor function has been well accepted due to identification of functional IGFBP-3-interacting proteins, putative receptors, or crosstalk with other signaling cascades. This review mainly focuses on transmembrane protein 219 (TMEM219), which represents a novel IGFBP-3 receptor mediating antitumor effect of IGFBP-3. Furthermore, this review delineates the potential underlying mechanisms involved and the subsequent biological significance, emphasizing the clinical significance of the IGFBP-3/TMEM219 axis in assessing both the diagnosis and the prognosis of cancer as well as the therapeutic potential of TMEM219 agonists for cancer treatment.
\end{abstract}

Keywords: IGF system; IGFBP-3; IGFBP-3R; TMEM219; anti-tumor; anti-metastatic; agonists; mAb therapy

\section{Introduction}

The insulin-like growth factor (IGF) system comprises of ligands IGF-I, IGF-II, its corresponding cell-membrane receptors IGF-I receptor (IGF-IR), IGF-II receptor (IGF-IIR), IGF-binding proteins (IGFBPs), and IGFBP degrading enzymes known as proteases. The IGF system plays a critical role in somatic growth in an endocrine fashion as well as cell proliferation, survival, and differentiation of normal and malignant cells in a paracrine/autocrine fashion. Dysregulation of the IGF system attributes to pathophysiology of a variety of human diseases such as cancer, diabetes, chronic inflammatory disease, and malnutrition. In particular, IGF/IGF-IR-independent actions of IGFBP-3 have been extensively investigated and their involvement in initiation and progression of various cancers has been recognized. 


\section{IGFBP-3}

\subsection{Structure-Function Analysis}

Human IGFBP-3 is comprised of 264 amino acids, of which the molecular mass is $28.7 \mathrm{kDa}$ without any post-translational modifications [1]. The primary structures of human IGFBP-3 consist of three distinct domains: a highly conserved cysteine-rich $N$ - and $C$-terminal domains and a nonconserved central domain. Each domain contains various functional motifs/sequences that confer IGFBP-3's diverse IGF/IGF-IR-dependent and IGF/IGF-IR-independent actions (Figure 1) [2-6]. These distinctive functional motifs/sequences include a caveolin scaffolding docking domain, a metal binding domain, heparin binding motifs, a retinoic acid binding motif, and a nuclear localization sequence.

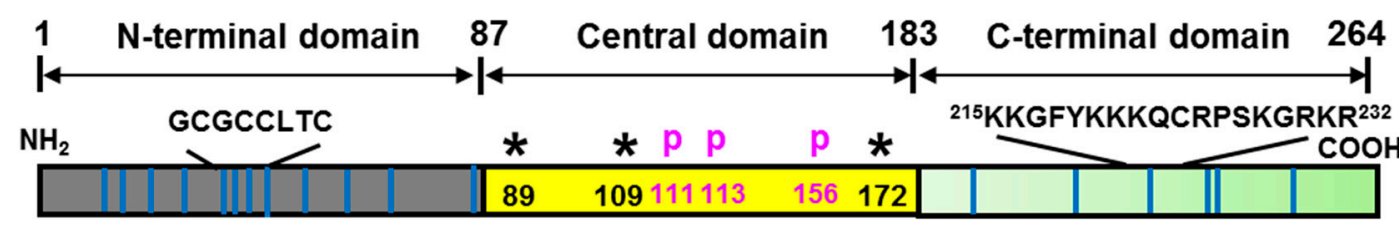

\begin{tabular}{|c|c|c|}
\hline $\begin{array}{l}\text { *Similar modular construction } \\
\text { among six high-affinity } \\
\text { IGFBPs - } 58 \% \\
\text { *Cysteine rich regions ( } 12 \\
\text { cysteines) } \\
\text { *IGFBP motif - GCGCCXXC } \\
\text { *Primary IGF binding domain } \\
\text { * Known IGF-binding residues } \\
\text { including } \mathrm{I}^{56}, \mathrm{~L}^{80}, \mathrm{~L}^{81}\end{array}$ & $\begin{array}{l}\text { *Highly variable central } \\
\text { domain - only } 15 \% \text { similarity } \\
\text { with other high-affinity } \\
\text { IGFBPs } \\
\text { *posttranslational } \\
\text { modifications [glycosylation } \\
(*) \text {, phosphorylation (p)] } \\
\text { *IGFBP-3 cell surface } \\
\text { association with IGFBP-3 } \\
\text { receptor, transmembrane } \\
\text { protein } 219 \text { (TMEM } 219 \text { ) } \\
\text { *Proteolytic sites for IGFBP-3 } \\
\text { proteases are found in this } \\
\text { domain } \\
\text { *Acting as a hinge to bring the } \\
\text { N- and C-terminal domains } \\
\text { into close proximity to create a } \\
\text { high affinity IGF binding } \\
\text { pocket }\end{array}$ & $\begin{array}{l}\text { *Similar modular construction } \\
\text { among six high-affinity IGFBPs - } \\
34 \% \\
\text { * Cysteine rich region (6 cysteines) } \\
\text { *IGF binding domain } \\
\text { *18 residue basic motif - binds } \\
\text { heparin, other glycosaminoglycans, } \\
\text { proteoglycans, fibrinogen, fibrin } \\
\text { *Humanin, low-density lipoprotein } \\
\text { receptor-related protein-1 (LRP-1) } \\
\text { receptor binding domain } \\
\text { *Acid-labile subunit (ALS) and } \\
\text { Transferrin binding region } \\
\left({ }^{228} \text { KGRKR }{ }^{232} \text { ) }\right. \\
\text { *Nuclear localization sequence } \\
\left({ }^{215} \text { KKGFYKKKQCRPSKGR }{ }^{230} \text { ) }\right. \\
\text { interacts with importin } \beta \text { factor } \\
\text { *Caveolin scaffolding docking } \\
\text { domain ( }{ }^{234} \text { FCWCVDKY } \\
\text { *Metal binding domain } \\
(223 \text { QCRPSKGRKRGFCW } 236 \text { ) }\end{array}$ \\
\hline
\end{tabular}

Figure 1. Structure of the mature human IGFBP-3. This figure depicts the three distinct domains of the IGFBP-3 and lists the important functions and motifs/residues within each domain [3]. The vertical blue lines represent 18 cysteine residues in highly conserved $N$-terminal and $C$-terminal domains.

\subsubsection{The Conserved N-Terminal Domain}

In the mature IGFBP-3 peptide, amino acid residues 1-87 comprise the conserved N-terminal domain, which shares approximately $58 \%$ similarity with other high-affinity IGFBPs. A well conserved IGFBP motif (GCGCCXXC) present in all IGFBP species is located in this domain. Ten to 12 of the 16-20 cysteines are located in the $N$-terminal domain of high-affinity IGFBPs. Among a total of 18 cysteines in IGFBP-3, 12 cysteines reside in the $N$-terminal domain, which results in the formation of six disulfide bonds within the domain and providing a highly organized tertiary structure. Thus, this conserved $N$-terminal domain shares not only amino acid similarity but also conformational similarities among high-affinity IGFBPs. Important IGF-binding residues including I56, L80, and L81 are also located within this domain $[2,3,7]$. 


\subsubsection{The Variable Central Domain}

The central domain contains 95 amino acids and spans residues 88-183. This domain separates the $\mathrm{N}$-terminal domain from the $\mathrm{C}$-terminal domain and shares less than $15 \%$ similarity with other high-affinity IGFBPs [2]. However, it appears that this domain structurally acts as a hinge between the $\mathrm{N}$ - and $\mathrm{C}$-terminal domains and bring two domains together into close proximity to create a high affinity IGF binding pocket. Post-translational modifications such as glycosylation, phosphorylation, and proteolysis of IGFBP-3 have been found in this domain [8-12]. The functional significance of those post-translational modifications has been reported that glycosylation can affect cell interactions, that phosphorylation can affect IGF-binding affinity and susceptibility to proteases, and that proteolysis can affect both IGF-dependent and IGF-independent actions [4,11-13]. Three $N$-linked glycosylation sites at asparagine 89,109, and 172, and phosphorylation sites at serine 111,113, 156, 165, and at threonine 170, as well as proteolytic sites for metalloproteases (MMPs) and serine proteases exist in this domain $[8-10,12,13]$. The central domain is responsible for the interaction with the IGFBP-3 specific receptor known as transmembrane protein 219 (TMEM219) [14,15].

\subsubsection{The Conserved C-Terminal Domain}

This domain spans residues 184-264, containing six cysteines with three disulfide bonds. This domain is also important in IGF binding [16-19]. Since the IGFBP-3 fragment that contains only $\mathrm{N}$ - or $\mathrm{C}$-terminal domains has significantly reduced affinity for IGFs, it requires an IGF-binding pocket involving both domains for high affinity binding to IGFs. Several functionally important sequences/motifs are present in this domain such as binding for heparin, glycosaminoglycans, proteoglycans, fibronectin, fibrin, transferrin, plasminogen, acid-labile subunit (ALS), and metals such as iron, zinc, and nickel [3-5,20-24]. Both IGFBP-3 and IGFBP-3-IGF complexes bind fibrinogen, fibrin, and plasminogen. Furthermore, a nuclear localization sequence (NLS) [25] and a caveolin-scaffolding domain consensus sequence [26] also reside in this domain.

\subsection{IGF/IGF-IR Dependent Actions of IGFBP-3}

The principal action of IGFBP-3 is to transport IGF-I and IGF-II in circulation, and, thereby, prolong the half-life of IGFs. IGFBP-3 has a higher affinity for IGFs (Kd approximately $10^{-10} \mathrm{M}$ ) than their respective receptors. In serum, most of the IGFs circulate as a $150 \mathrm{kDa}$ complex, consisting of 7.5 kDa IGF-I or IGF-II and 45 kDa glycosylated IGFBP-3 and $90 \mathrm{kDa}$ ALS [3-5,27-29]. The biological activity of circulating IGFs in the tissues is determined by the transition of IGF from $150 \mathrm{kDa}$ complex to the $55 \mathrm{kDa}$ IGF-IGFBP-3 complex and subsequent proteolysis of the complex to release IGF in the circulation or in the local body fluid. In addition to functioning as an IGF transporter, IGFBP-3 also functions as modulators of IGF availability and activity at the cellular levels in an autocrine or paracrine manner [25,28-32].

IGFBP-3 can inhibit or enhance IGF actions, depending on cell types, the cellular environment, IGFBP-3 concentration, and post-translational modifications such as glycosylation, proteolysis, and phosphorylation [4,11-13]. IGFBP-3 has shown to inhibit IGF activity by competitively binding IGFs and preventing its binding to IGFRs $[29,30]$. On the other hand, IGFBP-3 can enhance IGF activity by increasing IGF concentration in the extracellular microenvironment by binding to heparin and proteoglycans, and, thereby, acting as a reservoir of IGFs [20-22].

\subsection{IGF/IGF-IR Independent Actions of IGFBP-3}

The IGF/IGF-IR-independent actions of IGFBP-3 have been shown to contribute to the pathophysiology of various human diseases such as cancer, diabetes, obesity, fatty liver disease, ischemia, and Alzheimer's disease [15,33-47]. In an early era of IGFBP-3 research in cancer, many studies demonstrated that IGFBP-3 is upregulated by different types of cell growth inhibitors at the transcriptional level in a variety of human cancer cells. These include anti-estrogens (Tamoxifen, 
ICI-182780), TGF- $\beta$, retinoic acid, TNF- $\alpha$, vitamin D, histone deacetylase inhibitor sodium butyrate, and anti-cancer dietary components including silibinin, apigenin, lycopene, resveratrol, curcumin, and quercetin [48-57]. In particular, the tumor suppressor gene p53 has been shown to upregulate IGFBP-3 at the transcriptional level $[58,59]$. Two p53 binding sites, Box A and Box B, were identified in the first and second introns of the IGFBP- 3 gene, based on homology to the p53 binding consensus sequence [58]. Further studies using p53 mutants have revealed a link between p53's activation of IGFBP-3 transcription and its induction of apoptosis by showing that the mutants that lost the ability to activate IGFBP-3 could not induce apoptosis [60]. Further research also demonstrated that the transfection of doxycycline-inducible p53 plasmids resulted in increased expression of p53 and IGFBP-3 and, subsequently, induced apoptosis in p53-negative PC-3 prostate cancer cells [40]. This p53-depedent induction of apoptosis was inhibited by treating with IGF-I, IGFBP-3 blocking antibodies, and IGFBP-3 antisense oligonucleotides, which demonstrated p53-dependent IGFBP-3's proapoptotic function. In light of p53 dependency of IGFBP-3 expression, $\Delta \mathrm{Np} 63 \alpha$, an isoform of tumor suppressor p63 with both dominant negative $(\Delta \mathrm{N})$ activities and a potent repressor of p53-mediated transactivation has been demonstrated to suppress expression of IGFBP-3 [61]. It appears that $\Delta \mathrm{Np} 63 \alpha$ binds the p53 binding sites, Box A and Box B, in the IGFBP-3 gene, and, thereby, inhibits p53-dependent IGFBP-3 expression and presumably suppresses IGFBP-3-induced apoptosis. However, evidence also supports that IGFBP-3 can be induced in a p53-independet manner [40]. Treatment with genotoxic drugs such as etoposide and Adriamycin resulted in increased IGFBP-3 expression in p53-negative PC-3 prostate cancer cells.

Moreover, several studies demonstrated that the loss of IGFBP-3 expression by DNA methylation is linked to tumorigenesis and cancer progression as well as intrinsic and/or acquired resistance to radiotherapy and chemo-drugs such as cisplatin in many different types of cancer including lung, colon, and ovarian cancers [62-69]. These findings strongly suggested that IGFBP-3 may exert anti-proliferative and anti-tumor functions beyond its ability to modulate IGF functions (IGF/IGF-IR dependent actions), but the underlying mechanisms involved remain largely unknown. Since then, there has been an intensive investigation toward characterizing the molecular and cellular mechanisms for IGF/IGF-IR-independent antitumor effects of IGFBP-3 in human cancer in vitro and in vivo. It is clear that IGFBP-3 exerts its IGF/IGF-IR-independent biological actions through interactions with a variety of binding partners on cell surfaces and within cells.

\subsubsection{IGFBP-3 Binding Partners on the Cell Surface}

The very first evidence for the IGF/IGF-IR-independent actions of IGFBP-3 was the identification of specific cell surface binding between IGFBP-3 and cell surface proteins and subsequent cell growth inhibition in Hs578T human triple negative breast cancer (TNBC) cells [33,70]. These initial findings demonstrated that only IGFBP-3 specifically binds to the cell surface among IGFBPs and the central domain of IGFBP-3 is necessary for the binding. IGFs attenuated the cell surface binding and the subsequent growth inhibitory effects of IGFBP-3 by forming IGF-IGFBP-3 complexes. The existence of high-affinity binding sites for IGFBP-3, which is typical of receptor-ligand interactions, were found. The binding sites further demonstrated 20- and 28-kDa cell surface proteins as putative receptors. Based on biochemical and functional characteristics, these proteins are later proven to be an IGFBP-3 receptor, TMEM219, which was identified by a yeast two-hybrid screening using the central domain of IGFBP-3 from the same Hs578T human TNBC cell line [15]. This IGFBP-3 receptor will be further discussed in Section 3.

At present, a few proteins have been identified as IGFBP-3 cell surface binding partners such as the low-density lipoprotein receptor-related protein-1 (LRP-1)/ $\alpha 2 \mathrm{M}$ receptor [71], autocrine motility factor (AMF)/phosphoglucose isomerase (PGI) [72], latent TGF- $\beta$ binding protein-1 (LTBP-1), caveolin, and transferrin/transferrin receptor [26,73]. The LRP-1/ $\alpha 2 \mathrm{M}$ receptor, also known as TGF- $\beta$ type V receptor, is shown to mediate IGFBP-3-induced cell growth inhibition independent of IGF [74,75]. In addition, it plays a crucial role for cellular internalization of IGFBP-3 since LRP knock-out cells exhibited 
significant reduction of IGFBP-3 internalization when compared with LRP-expressing mouse embryonic fibroblasts [76]. While AMF/PGI, which is a tumor-secreted cytokine, is endocytosed and regulates cell migration, proliferation, and survival, IGFBP-3 has been shown to inhibit AMF/PGI-induced cell migration in T47D and MCF-7 breast cancer cells [72]. LTBP-1, which is a component of the latent TGF- $\beta$ complex and a part of structural component of the ECM, is involved in sequestration of latent TGF- $\beta$ in the ECM and delivery of TGF- $\beta$ to the plasma membrane [77]. Although the functional significance of IGFBP-3 binding to LTBP-1 as well as the large latent complex has not been fully elucidated, it may be a potential mechanism whereby IGFBP-3 can interact with the TGF- $\beta$ system [78]. Since a substantial amount of LTBP- 1 can be secreted by cells without bound TGF- $\beta$, IGFBP-3 may also involve TGF- $\beta$-independent functions of LTBP-1 [79].

IGFBP-3 interaction with caveolin-1 through a caveolin-scaffolding sequence induced IGFBP-3 internalization [26]. Furthermore, recent research indicated that caveolin-1 is an oncogenic membrane protein and is associated with endocytosis, extracellular matrix organization, cholesterol distribution, cell migration, and signaling. This strongly suggests the potential regulation of IGFBP-3 on these caveolin-1-induced functions [80]. IGFBP-3 also binds to transferrin and forms an IGFBP-3-tranferrin-transferrin receptor complex, providing another mechanism for IGFBP-3 internalization and signaling [26,73]. IGFBP-3 internalization was inhibited by co-incubation and extracellular sequestration with IGF-I, and was dependent on the transferrin-binding C-terminal peptide region of IGFBP-3 [26]. By the same token, blocking transferrin receptor-mediated endocytosis suppressed IGFBP-3 internalization and IGFBP-3-induced apoptosis [26]. At present, it remains unclear whether TMEM219 is a sole IGFBP-3 receptor mediating IGF/IGF-IR independent antitumor actions of IGFBP-3 or whether the previously mentioned cell surface binding partners are also partly involved in IGFBP-3 internalization and subsequent IGF/IGF-IR independent actions in cytoplasmic and nuclear compartments.

\subsubsection{IGFBP-3 Binding Partners within Cells}

Although IGFBP-3 can be internalized to the cytoplasmic compartment and translocated to the nucleus through the NLS in the conserved C-terminal domain, limited knowledge is available on whether nuclear targeting of IGFBP-3 occurs in all types of cells or requires specific cellular conditions. Nevertheless, IGFBP-3 has been shown to interact with cytoplasmic/nuclear proteins. These include humanin [37], RNA polymerase II binding subunit 3 (Rpb3) [81], GalNAc-T14 [82], glucose-regulated protein 78 (GRP78) [83,84], nuclear retinoid X receptor (RXR) [85], retinoic acid receptor (RAR) [86], Nur77 [87], vitamin D receptor (VDR) [88], and peroxisome proliferator-activated receptor- $\gamma(\operatorname{PPAR} \gamma)$ [89].

Humanin is a mitochondrial-derived peptide that inhibits neuronal cell death induced by mutant genes in Alzheimer's disease [37]. Humanin has been shown to bind to IGFBP-3 and inhibit nuclear translocation and induction of apoptosis of IGFBP-3 in human lung cancer cells by suppressing the IGFBP-3 interaction with importin- $\beta$ [90]. Rpb3, which is an essential component of the mRNA transcription apparatus, aids the recruitment of the polymerase complex to specific transcription factors. Rpb3 has been shown to interact with the NLS motif of IGFBP-3 and might lead to IGFBP-3's role in modulating gene transcription [81]. GalNAc-T14, a large subfamily of glycosyltransferases residing in the Golgi complex, catalyze the first step in the $O$-glycosylation of mammalian proteins by transferring N-acetyl-D-galactosamine (GalNAc) to peptide substrates [91]. Since GalNAc-T14 has been shown to be associated with poor recurrence-free survival and promote cell migration and invasion as well as metastasis through the Wnt signaling in lung cancer [92], IGFBP-3 may interfere with pro-tumorigenic and pro-metastatic GalNAc-T14 signaling by complexing with GalNAc-T14 in certain types of cancer including lung cancer. On the other hand, GalNAc-T14 has been also shown to inhibit IGFBP-3-induced cell proliferation and colony formation in glioblastoma cells. Although overexpression of IGFBP-3 induced expression of Cyclin E, CDK2, and p-ERK1/2, and overexpression of 
GalNAc-T14 inhibited these IGFBP-3 effects in glioblastoma cells, no evidence was presented whether direct binding of these two proteins is involved in observed biological outcomes [93].

GRP78, which is also known as immunoglobulin heavy-chain binding immunoglobulin protein (BiP), plays a critical role for endoplasmic reticulum integrity and stress-induced autophagy in mammalian cells [94]. When unfolded or misfolded proteins accumulate in the ER (called ER stress), an unfolded protein response (UPR) is activated through the induction of GRP78 as the first defense response, which, thereby, restores normal function of the ER by attenuating global translation and increasing the folding capacity of the ER [95]. It has been shown that the elevated expression of GRP78 is correlated with cancer malignancy, metastasis, and drug resistance in a variety of cancers, including breast cancer, prostate cancer, lung cancer, and glioma [96]. In line with these findings, GRP78 has been further shown to possess pro-survival and anti-apoptotic properties [97]. Interaction of IGFBP-3 and GRP78 has been identified in human breast cancer cells using a yeast two-hybrid screening [83]. In this study, overexpression of IGFBP-3 showed that IGFBP-3 binding to GRP78 results in the disruption of the GRP78-caspase-7 complex, which, thereby, activates caspase-7, and, subsequently, induces apoptosis in anti-estrogen-resistant breast cancer cells. These findings strongly suggest that IGFBP-3 could sensitize anti-estrogen-resistant breast cancer cells to anti-estrogen such as ICI 182,780 by preventing the anti-apoptotic function of GRP78. On the contrary, IGFBP-3 has been shown to enhance the survival of cells subjected to glucose starvation and hypoxia by inducing autophagy in a GRP78-dependent manner in human breast cancer cells, which suggests that IGFBP-3 may play a key role in mediating an autophagic survival response [84]. Although the biological outcomes of IGFBP-3 are much different depending on the cellular environment, it is clear that the specific interaction of GRP78 and IGFBP-3 is attributed to the observed IGFBP-3 effects.

IGFBP-3 has also been shown to inhibit cell growth and induce apoptosis through an interaction with nuclear proteins such as retinoid X receptor (RXR)- $\alpha$, retinoic acid receptor (RAR), and Nur77 [98]. RXR is involved in physiological functions of thyroid hormone, steroid hormones, embryonic development, apoptosis, and homeostasis [99-101]. RXR heterodimerizes with Nur77, a nuclear receptor transcription factor, and, thereby, enhances its DNA binding ability and regulates apoptosis in various cancers [102]. IGFBP- 3 binds RXR- $\alpha$ and RAR and, subsequently, modulates RAR/RXR and RXR/Nur77 signaling, which, thereby, induces apoptosis [81,82]. It has been further shown that Nur77 translocates to the nucleus and initiates apoptosis in the presence of IGFBP-3 [98]. However, recent studies also showed that IGFBP-3 mutants that failed to translocate to the nucleus and lost binding ability to RXR- $\alpha$, still induced apoptosis in breast cancer cells $[103,104]$. This suggests that IGFBP-3 may either utilize multiple mechanisms for its anti-tumor actions depending upon the cellular environment or the observed IGFBP-3 interaction with cytoplasmic/nuclear partners may not represent major IGFBP-3 anti-tumor signaling. It is clear that IGFBP-3 exerts a pro-apoptotic and anti-proliferative IGF/IGF-IR independent actions through multiple mechanisms such as an interaction with the IGFBP-3 receptor and other binding partners on the cell surface and within cells as well as nuclear association. The remainder of this review will focus on the IGFBP-3 receptor TMEM219 in human cancer by mainly providing the evidence to date regarding the IGFBP-3/TMEM219 system as an anti-tumor and anti-metastatic signaling in human cancer.

\section{TMEM219 as an IGFBP-3 Specific Receptor}

Early studies in the IGF/IGF-IR-independent actions of IGFBP-3 have been shown that IGFBP-3 binding to a cell surface protein is required for its anti-proliferative action in human breast cancer cells and that the central domain of IGFBP-3, which is the least conserved region among IGFBPs 1-6, is responsible for cell surface binding $[33,70,105]$. Furthermore, IGFBP- 3 has been shown to induce apoptosis by activating caspase- 8 cleavage, but not cytochrome c release or caspase- 9 cleavage involved in the death receptor-mediated apoptotic pathways in MCF-7 breast cancer cells [106]. These findings strongly suggested the existence of an IGFBP-3-specific receptor mediating the direct anti-proliferative and pro-apoptotic effects of IGFBP-3 in a variety of cancer cells. 
As an effort to identify a novel cell death receptor specific for IGFBP-3, yeast two-hybrid screening was employed using a cDNA construct encoding amino acid residues 88-148 of the variable central domain of IGFBP-3 as bait against an Hs578T human TNBC cell cDNA library. As a result, a functionally unknown transmembrane protein TMEM219 has been identified as an IGFBP-3 specific interacting protein and later designated as an IGFBP-3 receptor (IGFBP-3R) [15]. TMEM219 consists of four exons comprising the 915-base pair cDNA sequence on chromosome 16q13 and represents a 240-amino acid polypeptide. Further analysis of the deduced amino acid sequence indicated that the 202-residue mature human IGFBP-3R consists of an extracellular domain, a putative single-span transmembrane domain, and a short $C$-terminal cytoplasmic domain (Figure 2). The extracellular domain contains three potential $\mathrm{N}$-glycosylation sites and three phosphorylation sites. The transmembrane domain contains a leucine zipper-like heptad repeat pattern of amino acids that appear to involve dimerization/oligomerization of the membrane proteins. This very unique leucine zipper sequence is also present in the single-span transmembrane domain of the erythropoietin receptor and the discoidin domain receptor $[106,107]$. Additionally, IGFBP-3R activates caspase-8-induced apoptosis in unconventional ways: (1) IGFBP-3R and inactive procaspase- 8 is pre-complexed at the resting stage, and IGFBP-3 binding to IGFBP-3R releases procaspase-8, and, thereby, activates caspase-8-dependent apoptosis, and (2) IGFBP-3R complexes with procasepase-8 without involvement of a typical death domain (DD) sequence. The DD sequence in the intracellular portion of the receptor is required to form a death-inducing signaling complex (DISC) by recruiting adaptor proteins (FADD) and procaspase- 8 after receptor activation in various death receptors such as the TNF- $\alpha$ receptor, TNF-related apoptosis-inducing ligand receptor 1 (TRAIL-R1/DR4), TRAIL-R2 (APO-2/DR5), and CD95 (Fas, APO-1). However, similar to IGFBP-3R, a few other proteins have been shown to interact with caspase- 8 and induce apoptosis despite the lack of a DD sequence $[108,109]$. IGFBP-3R is located in both the plasma membrane and cytoplasm, but not in the nucleus of the cancer cells. This cell surface IGFBP-3R interacts specifically with IGFBP-3 but not with other high-affinity IGFBPs, activates procaspase-8, and mediates IGFBP-3-induced apoptosis in many different types of cancer cells and tumor suppression in both prostate and breast cancer xenograft mouse models. Further knockdown of IGFBP-3R attenuates IGFBP-3-induced caspase activities and apoptosis, whereas its overexpression elicited the opposite effects $[15,65,110,111]$. These findings clearly indicate that IGFBP-3R (TMEM219) is a bona fide IGFBP-3 receptor and mediates anti-tumor activities of IGFBP-3.

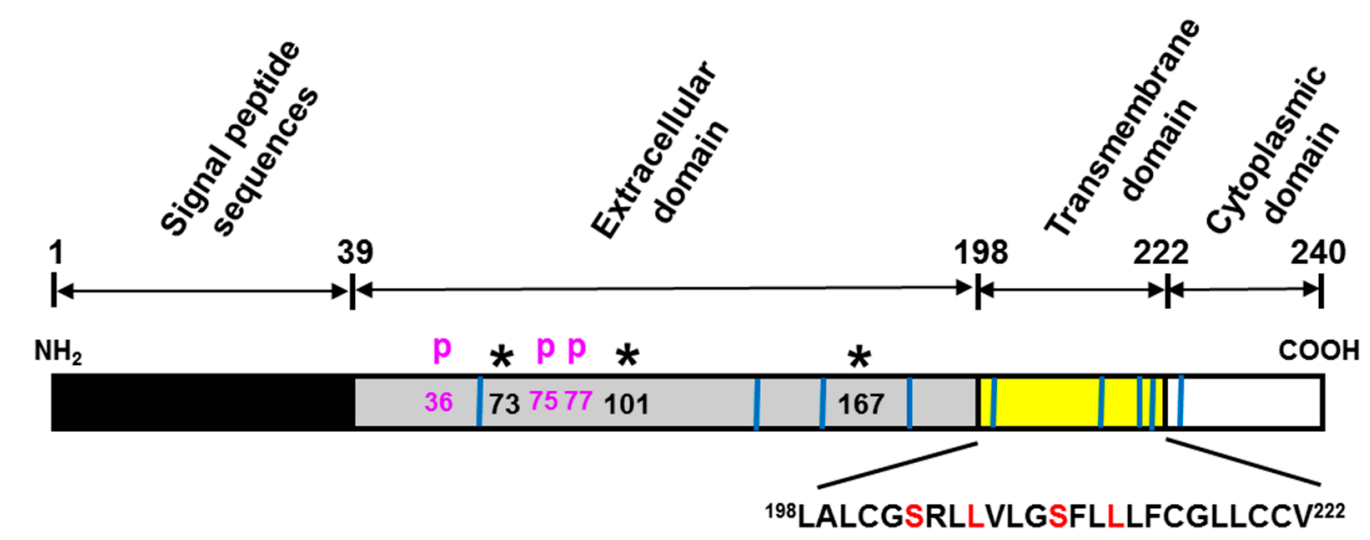

Figure 2. Structure of human IGFBP-3R (TMEM219). The 202-residue mature IGFBP-3R, omitting the 38-residue signal peptide, is comprised of three domains: extracellular, transmembrane, and cytoplasmic domains. Extracellular domain contains three potential N-glycosylation sites (residues 73, $101,167)$ and three potential phosphorylation sites (S36, T75, T77). The single-span transmembrane domain contains a leucine zipper-like heptad repeat pattern characteristic of leucine zipper interaction domains. The letters in red correspond to a-type and d-type interfacial residues in leucine zipper interaction domains [15]. The vertical blue lines represent nine cysteine residues. 
In addition, IGFBP-3 has been shown to suppress tumor-induced NF- $\mathrm{kB}$ activity via activation of caspase- 8 and caspase-3/7 in an IGF/IGF-IR-dependent manner in prostate cancer cells [111]. IGFBP-3 suppresses NF- $\mathrm{kB}$ activity in a unique way. It exerts caspase-induced degradation of I $\mathrm{K} \mathrm{B} \alpha$ and NF- $\mathrm{KB}$, but not other components such as IKK. IGFBP-3 also inhibited the expression of NF-KB-regulated factors such as VEGF, IL-8, ICAM-1, and VCAM-1. This inhibitory action of IGFBP-3 was IGF/IGF-IR-independent since the IGFBP-3 mutant devoid of IGF binding affinity had a similar inhibitory effect. Furthermore, IGFBP-3R has been shown to be responsible for IGFBP-3-induced suppression of NF-KB activity in cancer cells. These findings indicate that IGFBP-3 in addition to inducing apoptosis, also suppresses tumor-induced NF- $\mathrm{kB}$ activity, and, thereby, enhances the inhibition of tumor growth, angiogenesis, invasion, metastasis, and chemoresistance [111].

Recent reports further explored the therapeutic potential of the IGFBP-3/IGFBP-3R axis in cancer by developing an IGFBP-3R agonistic monoclonal antibody $(\mathrm{mAb})$ [112]. It has been shown that activation of IGFBP-3R by IGFBP-3 and IGFBP-3R agonistic $\mathrm{mAb}$ inhibits cell growth by inducing apoptosis and by tumor-induced NF- $\mathrm{kB}$ activity specifically in cancer cells, but not in normal cells. At present, for the cancer cell, specific pro-apoptotic properties of IGFBP-3 and IGFBP-3R agonistic $\mathrm{mAb}$ are not fully elucidated. However, a few potential mechanisms can be speculated based on the findings in tumor-specific targeting of the death receptor (DR)-4 and DR- 5 agonistic mAb therapy despite the presence of DR-4/DR-5 in normal cells [113-115]. These include: (1) decreased level of the cell surface DR-4/DR-5 in normal cells compared to cancer cells, (2) differential expression of unknown intracellular inhibitor(s) of apoptosis downstream of caspase-8, and (3) changes in apoptotic potency due to different glycosylation patterns of DRs.

In addition, IGFBP-3R agonistic mAb lost anti-proliferative effects in IGFBP-3R knockout cells. These in vitro data indicate that IGFBP-3R is indispensable for anti-tumor functions of IGFBP-3 and IGFBP-3R agonistic $\mathrm{mAb}$ in a variety of cancer cells. Further anti-tumor and anti-metastatic effects of IGFBP-3R agonistic $\mathrm{mAb}$ have been shown in vivo using MDA231 TNBC and patient-derived TNBC xenograft models [112]. Taken together, these findings provide evidence that IGFBP-3R (TMEM219) is a bona fide IGFBP-3 receptor and a potential target for cancer therapy.

\section{Clinical Insights of IGFBP-3/IGFBP-3R (TMEM219) System in Cancer}

Although IGFBP-3 may utilize multiple mechanisms for its anti-tumor actions, current findings suggest that the IGFBP-3/IGFBP-3R axis may constitute a novel anti-tumor/anti-metastatic signaling pathway and a novel potential therapeutic target in cancer. However, since limited knowledge is available on clinicopathologic significance and prognostic value of the IGFBP-3/IGFBP-3R system, the remainder of this review will focus on its clinical significance using data mining and analyses of publicly available databases including The Cell Index (CELLX) database (http://cellx.sourceforge.net) and The Cancer Genome Atlas (TCGA) database (https://portal.gdc.cancer.gov). Log2-transformed RSEM (RNA-Seq by Expectation-Maximization) [116] gene expression values were obtained.

\subsection{IGFBP-3 and TMEM219 Gene Expression in Tumor and Normal Samples}

Analysis of IGFBP-3 expression identified highly variable expression levels among different types of cancer as well as normal tissues (Figure 3). Further differential expression of IGFBP-3 was analyzed in cancers and the counterpart normal tissues where at least 12 normal samples were available (Table 1 ). 


\section{Tumor-Normal Expression, IGFBP3}

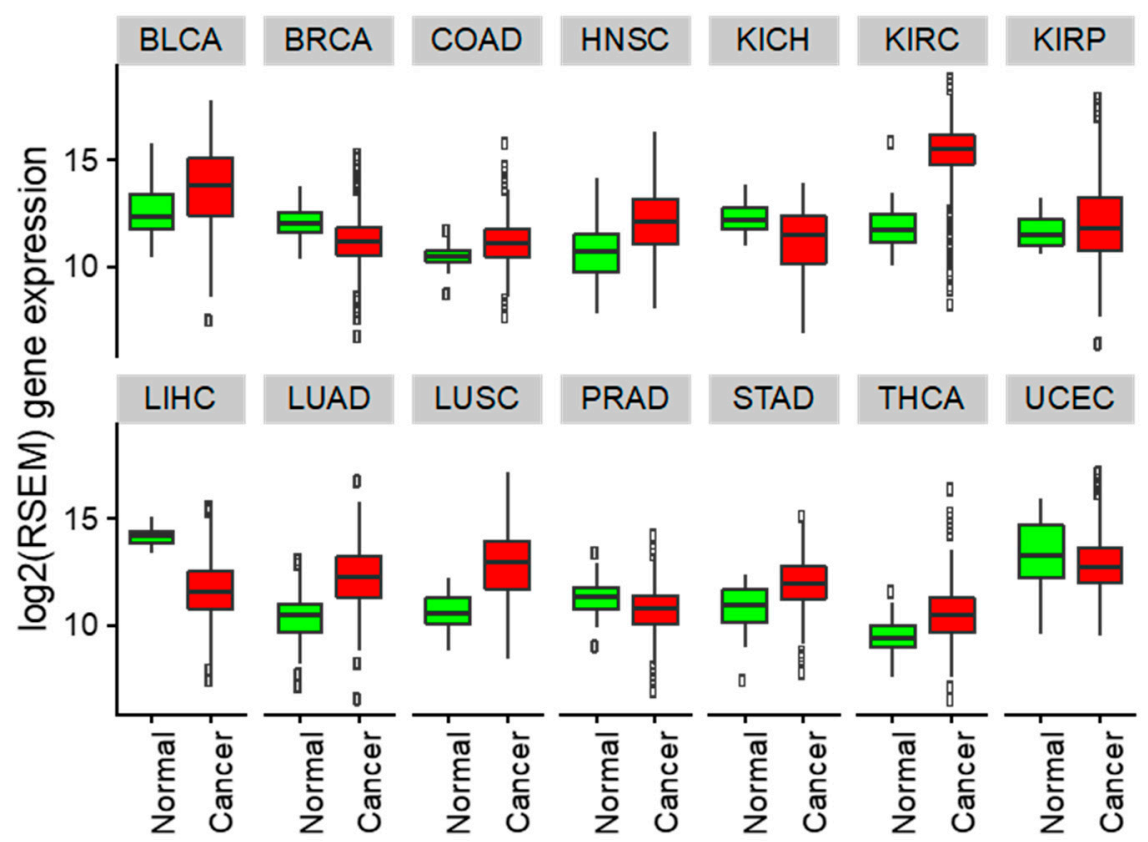

Figure 3. Cancer vs. normal IGFBP-3 log2 RSEM gene expression boxplots (all cancer). Description of abbreviations presented in Table 1.

Table 1. Differential expression of IGFBP-3. "Mean log2(RSEM)"-average gene expression in normal and cancer tissues, respectively. $t$-test $p$-values are shown.

\begin{tabular}{cccccc}
\hline TCGA ID & Description & $\begin{array}{c}\text { log2 Fold } \\
\text { Change }\end{array}$ & $p$-Value & $\begin{array}{c}\text { Mean } \\
\text { log2(RSEM) } \\
\text { Normal }\end{array}$ & $\begin{array}{c}\text { Mean } \\
\text { log2(RSEM) } \\
\text { Cancer }\end{array}$ \\
\hline KIRC & Upregulated in Tumor & & & & 15.30 \\
\hline LUSC & Lung squamous cell carcinoma & 2.26 & $1.2210^{-28}$ & 10.61 & 12.86 \\
\hline LUAD & Lung adenocarcinoma & 1.94 & $9.2810^{-21}$ & 10.31 & 12.26 \\
\hline HNSC & Head and Neck squamous cell carcinoma & 1.32 & $2.2910^{-7}$ & 10.82 & 12.14 \\
\hline STAD & Stomach adenocarcinoma & 1.18 & $8.6710^{-7}$ & 10.82 & 12.00 \\
\hline THCA & Thyroid carcinoma & 1.11 & $4.8510^{-16}$ & 9.46 & 10.57 \\
\hline BLCA & Bladder urothelial carcinoma & 1.05 & $3.5710^{-3}$ & 12.56 & 13.61 \\
\hline COAD & Colon adenocarcinoma & 0.65 & $4.0110^{-9}$ & 10.45 & 11.10 \\
\hline KIRP & Kidney renal papillary cell carcinoma & 0.34 & $5.1910^{-2}$ & 11.69 & 12.03 \\
\hline & Downregulated in Tumor & & & & 11.65 \\
\hline LIHC & Liver hepatocellular carcinoma & -2.53 & $4.1710^{-81}$ & 14.18 & 11.25 \\
\hline KICH & Kidney Chromophobe & -1.07 & $6.8010^{-5}$ & 12.32 & 11.23 \\
\hline BRCA & Breast invasive carcinoma & -0.82 & $9.7410^{-24}$ & 12.04 & 10.72 \\
\hline PRAD & Prostate adenocarcinoma & -0.56 & $1.4710^{-5}$ & 11.27 & 12.86 \\
\hline UCEC & Uterine Corpus Endometrial Carcinoma & -0.43 & $1.5310^{-1}$ & 13.29 & \\
\hline
\end{tabular}

Increased IGFBP-3 expression was observed in kidney renal clear cell carcinoma (log2 fold change +3.44 ), lung squamous cell carcinoma (log2 fold change +2.26 ), lung adenocarcinoma (log2 fold change $+1.94)$, head and neck squamous cell carcinoma ( $\log 2$ fold change +1.32$)$, stomach adenocarcinoma ( $\log 2$ fold change +1.18 ), thyroid carcinoma ( $\log 2$ fold change +1.11$)$, bladder urothelial carcinoma ( $\log 2$ fold change +1.05$)$, colon adenocarcinoma ( $\log 2$ fold change +0.65$)$, and kidney renal papillary 
cell carcinoma ( $\log 2$ fold change +0.34 ). On the other hand, decreased expression of IGFBP-3 was observed in liver hepatocellular carcinoma ( $\log 2$ fold change -2.53$)$, kidney chromophobe (log2 fold change -1.07$)$, breast invasive carcinoma ( $\log 2$ fold change -0.82$)$, prostate adenocarcinoma ( $\log 2$ fold change -0.56 ), and uterine corpus endometrial carcinoma (log2 fold change -0.43 ).

In the same datasets, TMEM219 expression also showed variable expression patterns, but had less variation when compared to IGFBP-3 among different types of cancer as well as normal tissues (Figure 4). Analysis of differential expression of TMEM219 revealed significant increased TMEM219 expression in 6 out of 14 tumors (Table 2). These include kidney renal papillary cell carcinoma (log2 fold change +0.53 ), thyroid carcinoma ( $\log 2$ fold change +0.40$)$, breast invasive carcinoma $(\log 2$ fold change +0.39$)$, kidney renal clear cell carcinoma ( $\log 2$ fold change +0.29$)$, bladder urothelial carcinoma ( $\log 2$ fold change +0.27$)$, and uterine corpus endometrial carcinoma ( $\log 2$ fold change +0.22$)$. On the contrary, decreased TMEM219 expression was observed in lung squamous cell carcinoma (log2 fold change -0.74$)$, stomach adenocarcinoma ( $\log 2$ fold change -0.42 ), colon adenocarcinoma (log2 fold change -0.36), head and neck squamous cell carcinoma (log2 fold change -0.32), lung adenocarcinoma ( $\log 2$ fold change -0.12 ), and kidney chromophobe (log2 fold change -0.10 ). In summary, these results suggest IGFBP-3 as a diagnostic biomarker and TMEM219 as a therapeutic target in certain types of tumors. Importantly, TMEM219 agonists may represent a novel therapy for tumors with significantly lower expression of IGFBP-3 but not TMEM219 compared to the counterpart normal tissues, such as breast invasive carcinoma, uterine corpus endometrial carcinoma, liver hepatocellular carcinoma, and prostate adenocarcinoma.

\section{Tumor-Normal Expression, TMEM219}

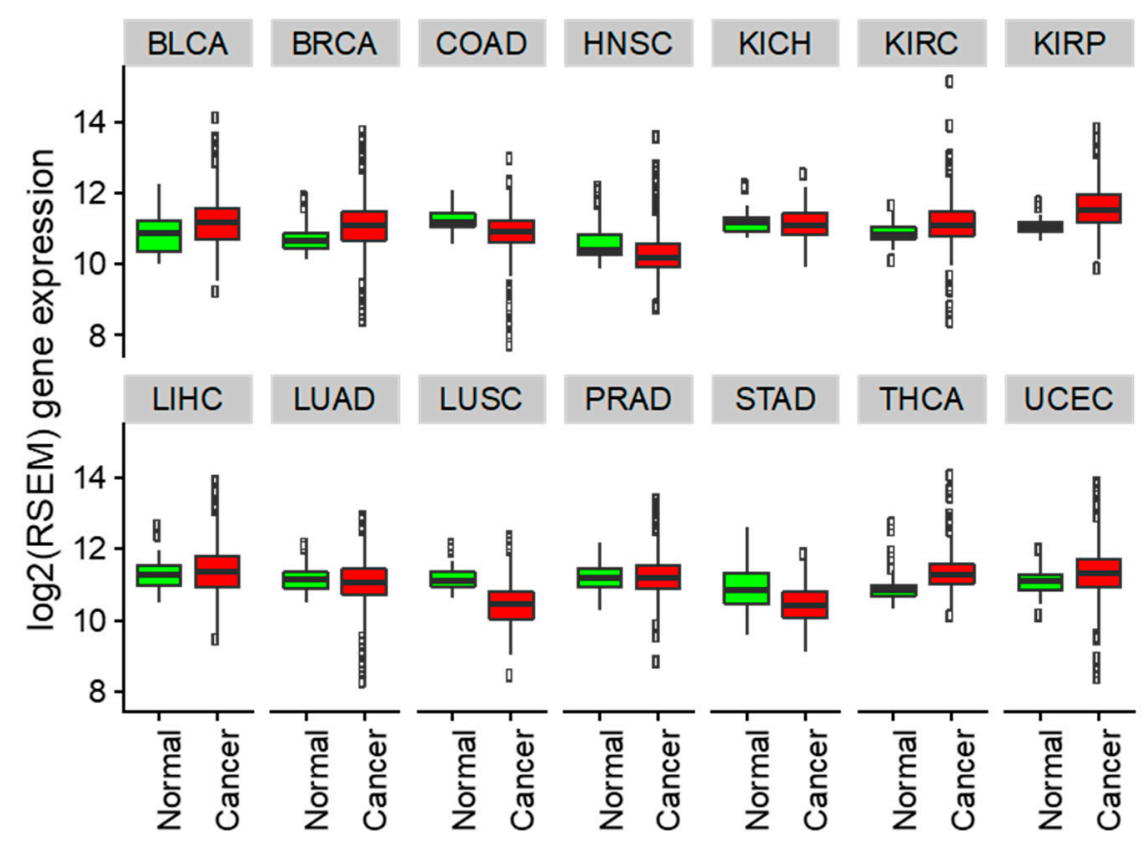

Figure 4. Cancer vs. normal TMEM219 log2 RSEM gene expression boxplots (all cancer). Description of abbreviations presented in Table 2. 
Table 2. Differential expression of TMEM219. "Mean log2 (RSEM)"—average gene expression in normal and cancer tissues, respectively. $t$-test $p$-values are shown.

\begin{tabular}{cccccc}
\hline TCGA ID & Description & $\begin{array}{c}\text { log2 Fold } \\
\text { Change }\end{array}$ & $p$-Value & $\begin{array}{c}\text { Mean } \\
\text { log2(RSEM) } \\
\text { Normal }\end{array}$ & $\begin{array}{c}\text { Mean } \\
\text { log2(RSEM) } \\
\text { Cancer }\end{array}$ \\
\hline \multicolumn{1}{c}{ KIRP } & Kidney renal papillary cell carcinoma & 0.53 & $3.1610^{-14}$ & 11.07 & 11.60 \\
\hline THCA & Thyroid carcinoma & 0.40 & $2.7710^{-8}$ & 10.94 & 11.34 \\
\hline BRCA & Breast invasive carcinoma & 0.39 & $1.0010^{-19}$ & 10.71 & 11.10 \\
\hline KIRC & Kidney renal clear cell carcinoma & 0.29 & $4.3010^{-11}$ & 10.88 & 11.18 \\
\hline BLCA & Bladder urothelial carcinoma & 0.27 & $1.0810^{-1}$ & 10.92 & 11.19 \\
\hline UCEC & Uterine Corpus Endometrial Carcinoma & 0.22 & $4.4710^{-3}$ & 11.10 & 11.32 \\
\hline LIHC & Liver hepatocellular carcinoma & 0.09 & $2.1110^{-1}$ & 11.30 & 11.39 \\
\hline PRAD & Prostate adenocarcinoma & 0.08 & $2.5210^{-1}$ & 11.18 & 11.26 \\
\hline \multicolumn{7}{c}{ DUSC } & Downregulated in Tumor & & & & 10.45 \\
\hline STAD & Lung squamous cell carcinoma & -0.74 & $6.5610^{-23}$ & 11.18 & 10.44 \\
\hline COAD & Stomach adenocarcinoma & -0.42 & $5.9310^{-4}$ & 10.86 & 10.89 \\
\hline HNSC & Colon adenocarcinoma & -0.36 & $1.4710^{-7}$ & 11.25 & 10.30 \\
\hline LUAD & Head and neck squamous cell carcinoma & -0.32 & $9.0010^{-4}$ & 10.63 & 11.06 \\
\hline KICH & Lung adenocarcinoma & -0.12 & $3.9710^{-2}$ & 11.18 & 11.14 \\
\hline
\end{tabular}

\subsection{Pan-Cancer Survival Effect of IGFBP-3 and TMEM219}

To investigate the effect of IGFBP-3 and TMEM219 expression on survival in clinical settings, the RNA-seq data from TCGA was analyzed (Figure 5). Gene expression data summarized as RSEM values were obtained using the TCGA2STAT R package v.1.2, along with the corresponding clinical annotations. Data for each of the 34 cancers were obtained separately. The data were log2-transformed and analyzed using Kaplan-Meier curves and the Cox proportional hazard model. Each gene of interest was analyzed for its effect on survival by separating patients into high/low expression subgroups. The scanning approach KaplanScan, used on the R2 Genomics web portal [117], was used to estimate the best gene expression cutoff that separates high/low expression subgroups with differential survival (R code modified from Reference [118]). In addition to survival analysis across all cancers, further survival analysis was performed within clinical subgroups of specific cancers, e.g., in "race-black or African-American" subgroup. $p$-values were corrected for multiple testing using the Benjamin-Hochberg (FDR) method [119] and reported throughout unless noted otherwise. Only subgroups with $>40$ patients were considered. This approach allowed us to understand the effect of IGFBP3 and TMEM219 expression on the level of individual cancers and in specific population subgroups. 

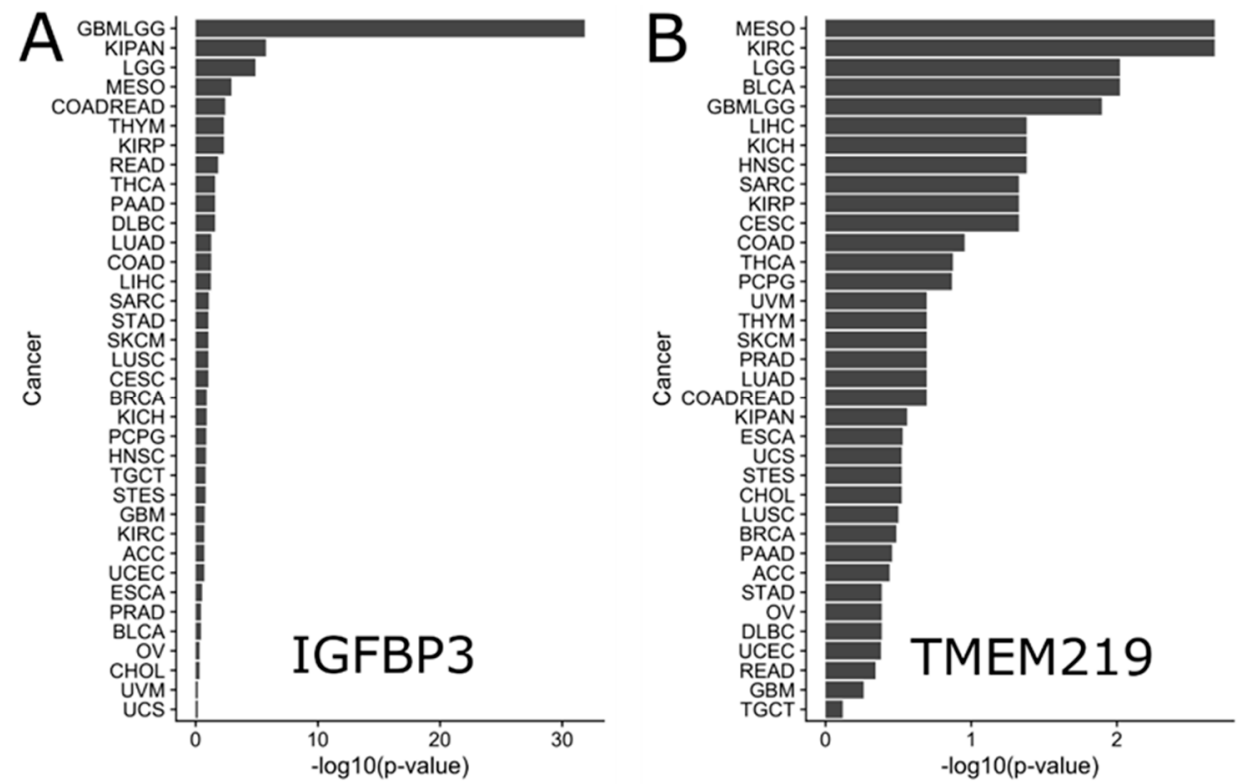

Figure 5. Survival effect of IGFBP-3 (A) and TMEM219 (B) in various cancers. Larger size of each bar corresponds to the more significant effect on survival.

Analysis of the survival effect of IGFBP-3 expression in all cancers identified its highly significant effect on survival in glioma $\left(\mathrm{FDR}=1.51 \cdot 10^{-32}\right.$ (Hazard Ratio, HR $\left.=4.39\right)$ ) (Figures 5A and 6A). Survival in pan-kidney cohort (KICH+KIRC+KIRP), lower grade glioma, mesothelioma, colorectal adenocarcinoma was similarly affected by IGFBP-3 to a lesser extent (FDR $=1.74 \cdot 10^{-6}(\mathrm{HR}=2.73)$, $1.25 \cdot 10^{-5}(\mathrm{HR}=2.36), 1.22 \cdot 10^{-3}$ ( $\left.\mathrm{HR}=2.98\right), 3.87 \cdot 10^{-3}$ ( $\left.\mathrm{HR}=2.20\right)$, respectively) (Figure 6B,C). On the other hand, higher IGFBP-3 was suggestive of better survival outcome in lymphoid neoplasm diffuse large B-cell lymphoma (FDR $\left.=2.58 \cdot 10^{-2}(\mathrm{HR}=0.14)\right)$, breast cancer $\left(1.20 \cdot 10^{-1}(\mathrm{HR}=0.74)\right)$, prostate adenocarcinoma $\left(3.43 \cdot 10^{-1}(\mathrm{HR}=0.51)\right)$, cholangiocarcinoma $\left(4.84 \cdot 10^{-1}(\mathrm{HR}=0.57)\right)$, bladder urothelial carcinoma $\left(3.63 \cdot 10^{-1}(\mathrm{HR}=0.84)\right)$, and uterine carcinosarcoma $\left(6.65 \cdot 10^{-1}(\mathrm{HR}=0.860)\right)$ (Figure 6D-F).

In summary, these results suggest IGFBP-3 as a prognostic biomarker in glioma, mesothelioma, kidney, and colorectal cancers with lower expression suggestive of better survival outcome, whereas diffuse large B-cell lymphoma, cholangiocarcinoma, bladder urothelial carcinoma, uterine carcinosarcoma, breast, and prostate cancer with higher expression suggestive of better survival outcome. Of note, the observed dichotomy of IGFBP-3 expression and patients' survival in various cancers may be attributed to other factors such as IGF-1/IGF-2 expression, IGFBP-3 polymorphism status, tumor suppressor p53 family status, tumor metabolic characteristics, and others. In addition, functional IGFBP-3 protein levels in circulation or in tumor and ratio of IGF-I and IGFBP-3 in circulation should be further factored to interpret the TCGA data. 

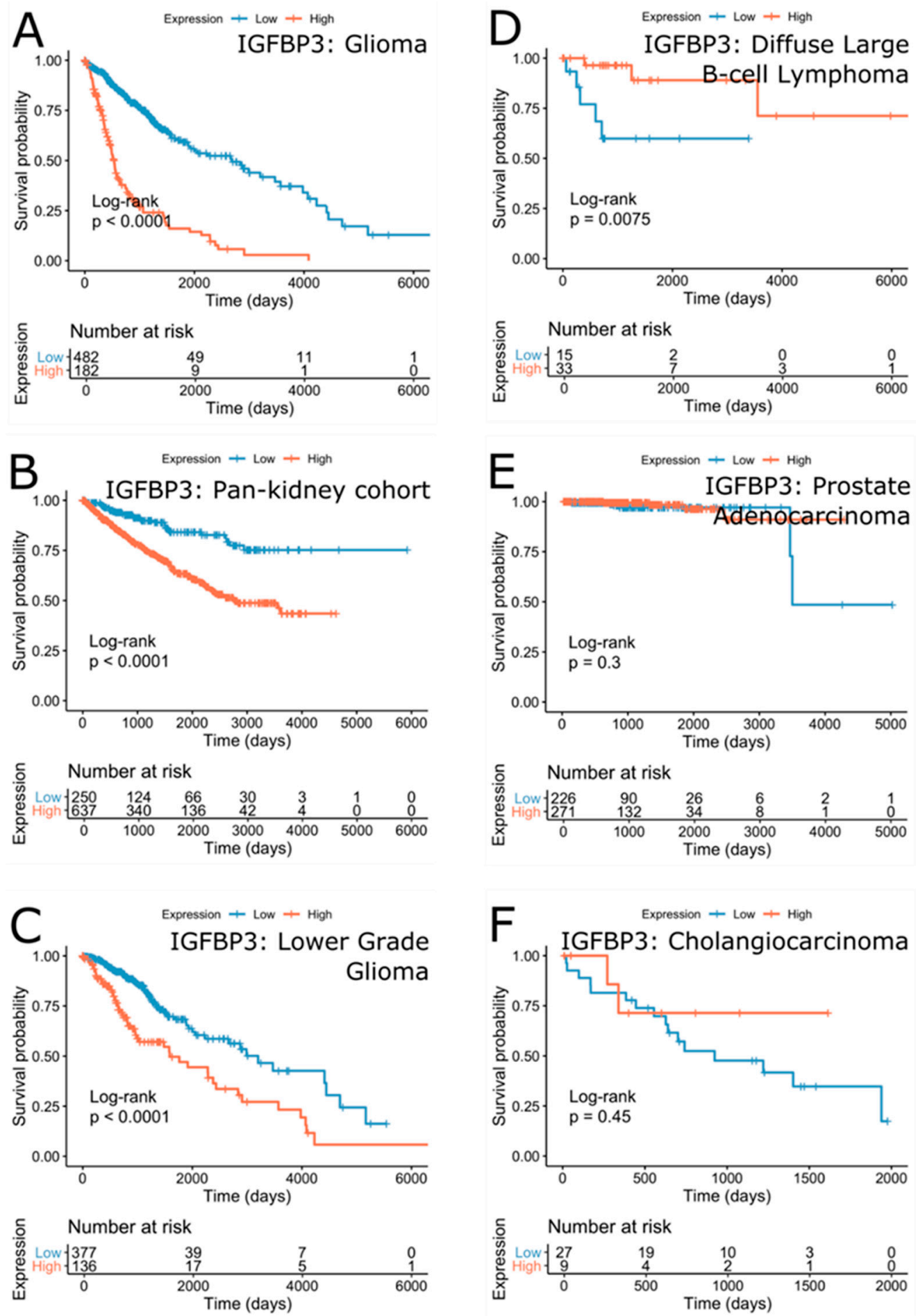

Figure 6. Kaplan-Meier plots of top cancers with survival outcomes separated by the expression of IGFBP-3 with a negative correlation (A-C) and a positive correlation (D-F). Unadjusted $p$-values are shown.

The TMEM219 survival effect was less significant than that of IGFBP-3 (Figure 5B). Nevertheless, the lower expression of the TMEM219 gene was associated with survival in kidney renal clear cell carcinoma (FDR $\left.=2.14 \cdot 10^{-3}(\mathrm{HR}=1.85)\right)$, glioma $\left(\mathrm{FDR}=1.27 \cdot 10^{-2}(\mathrm{HR}=1.56)\right)$, lymphoid neoplasm diffuse large B-cell lymphoma (FDR $=4.110 .54)$ ), head and neck squamous cell carcinoma (FDR = 4.17E-2 $(\mathrm{HR}=1.43))$ and pan-kidney cohort $(\mathrm{KICH}+\mathrm{KIRC}+\mathrm{KIRP})(\mathrm{FDR}=2.76 \mathrm{E}-1(\mathrm{HR}=1.2))($ Figure $7 \mathrm{~A}-\mathrm{C})$. On the contrary, the higher expression of TMEM219 was better for survival in mesothelioma (FDR = 
2.14E-3 $(\mathrm{HR}=0.39))$, lower grade glioma $(\mathrm{FDR}=9.54 \mathrm{E}-3(\mathrm{HR}=0.54))$, prostate adenocarcinoma (FDR $\left.=2.02 \cdot 10^{-1}(\mathrm{HR}=0.18)\right)$, thyroid carcinoma $\left(\mathrm{FDR}=1.332 \cdot 10^{-1}(\mathrm{HR}=0.39)\right)$ and bladder urothelial carcinoma $\left(\mathrm{FDR}=9.54 \cdot 10^{-3}(\mathrm{HR}=0.61)\right)($ Figure $7 \mathrm{D}-\mathrm{F})$.
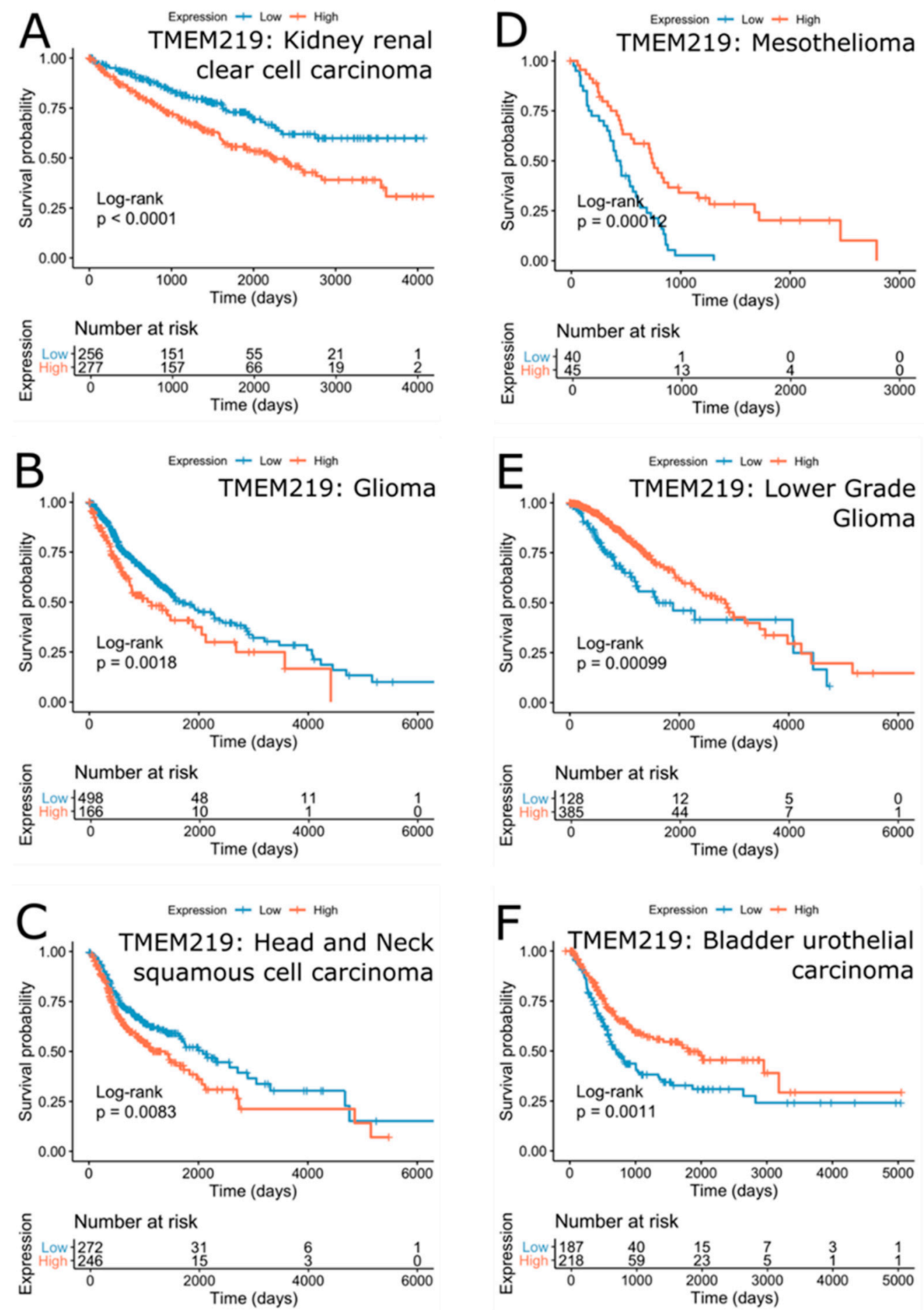

Figure 7. Kaplan-Meier plots of top cancers with survival outcomes separated by the expression of TMEM219 with a negative correlation (A-C) and a positive correlation (D-F). Unadjusted $p$-values are shown.

In addition to the cancer types expected to be affected by the IGFBP-3/TMEM219 system, bladder urothelial carcinoma and head and neck squamous cell carcinoma appear to be significantly associated 
with TMEM219 but not with IGFBP-3 expression. Higher TMEM219 expression was associated with better survival in bladder urothelial carcinoma $\left(\mathrm{FDR}=9.54 \cdot 10^{-3}(\mathrm{HR}=0.61)\right)$, while the reverse was true for head and neck squamous cell carcinoma (FDR $=4 \cdot 17 \cdot 10^{-2}(\mathrm{HR}=1.43)$ ). On the other hand, the expression of TMEM219 was not significantly associated with survival in breast cancer, while IGFBP-3 expression was positively associated with survival outcome (Figure 8). These results indicate that the effect of TMEM219 expression on survival is less pronounced and highly cancer-specific.
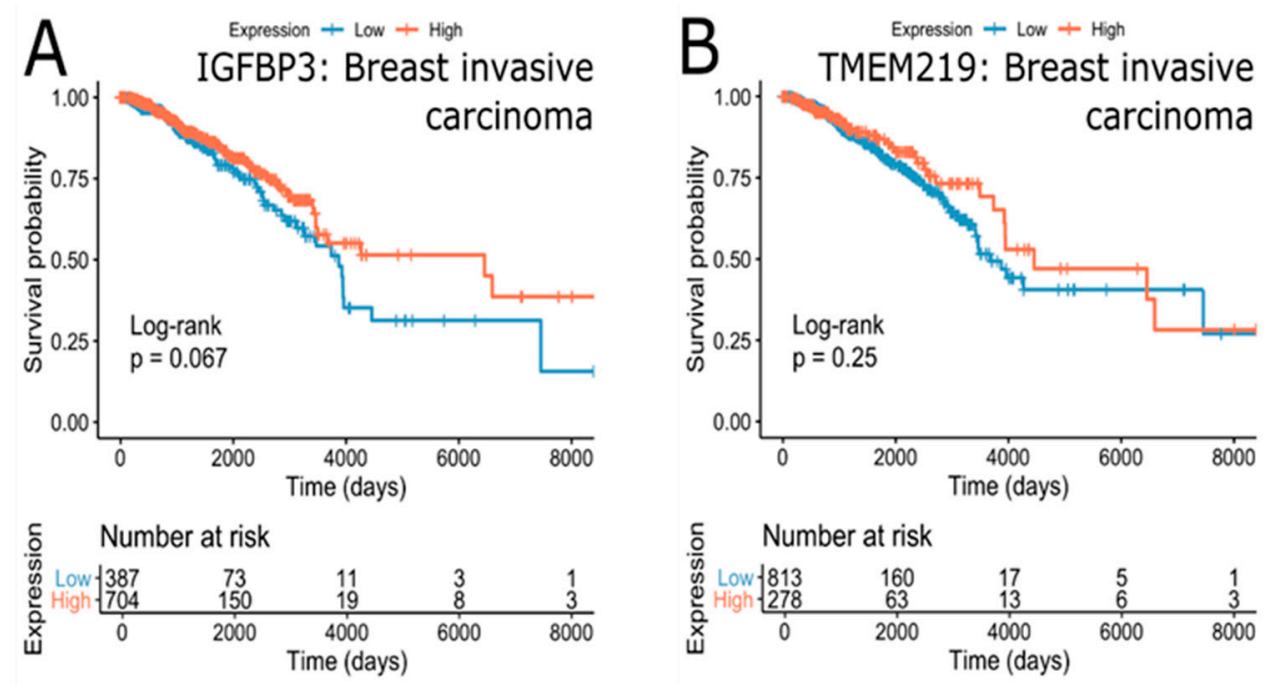

Figure 8. Kaplan-Meier plots of breast cancer cohort with survival outcomes separated by the expression of IGFBP-3 (A) and TMEM219 (B). Unadjusted $p$-values are shown.

\subsection{Survival Effect of IGFBP-3 and TMEM219 in Clinical Subcategories}

By taking advantage of the availability of clinical annotations, survival analysis of the effect of IGFBP-3 and TMEM219 expression in clinical subgroups, e.g., "race-black or African-American" was further performed. Similar to all cancer analyses, $p$-values were corrected for multiple testing across all tested subgroups in a given cancer. The advantage of such analyses is that they provide detailed insights into the effect of IGFBP-3 and TMEM219 in different subgroups of patients. The disadvantage is that some subgroups have an insufficient number of patients, e.g., in the "race-black or African-American" subgroup, which limits the cross-cancer comparisons.

Given the high significance of IGFBP-3 gene expression on survival outcome in glioma (FDR = $\left.1.51 \cdot 10^{-32}(\mathrm{HR}=4.39)\right)$, it was unsurprising that IGFBP-3 expression affected survival in nearly all glioma subgroups (FDR $<2.90 \cdot 10^{-2}$ ), with lower expression being associated with better survival outcome. Similarly, all subgroups in lower grade glioma were significantly associated with IGFBP-3 expression, with lower expression indicative of better survival outcome (FDR $\left.<5.82 \cdot 10^{-2}\right)$. Similar results were observed for clinical subgroups in mesothelioma, the pan-kidney cohort, rectum adenocarcinoma, colorectal adenocarcinoma, and colon adenocarcinoma cancers, where low expression of IGFBP-3 was similarly associated with better survival outcome. These results confirm previous observations that the expression of IGFBP-3 may affect survival in glioma, mesothelioma, kidney, and colorectal cancers.

Further analyses of the effect of IGFBP-3 and TMEM219 expression in specific clinical subgroups revealed that kidney renal papillary cell carcinoma is the only cancer where the expression of both IGFBP-3 and TMEM219 is marginally associated with survival in "race-black or the African-American" subgroup. Lower IGFBP-3 expression was beneficial for survival (FDR $=5.84 \cdot 10^{-2}(\mathrm{HR}=5.12)$ ), while higher TMEM219 expression was associated with better survival in the "race-black or African-American" subgroup ( $F D R=6.28 \cdot 10^{-2}(\mathrm{HR}=0.16)$ ), Figure 9). These results suggest the importance of the IGFBP-3/TMEM219 system in kidney renal papillary cell carcinoma in the "race-black or African-American" subgroup. 

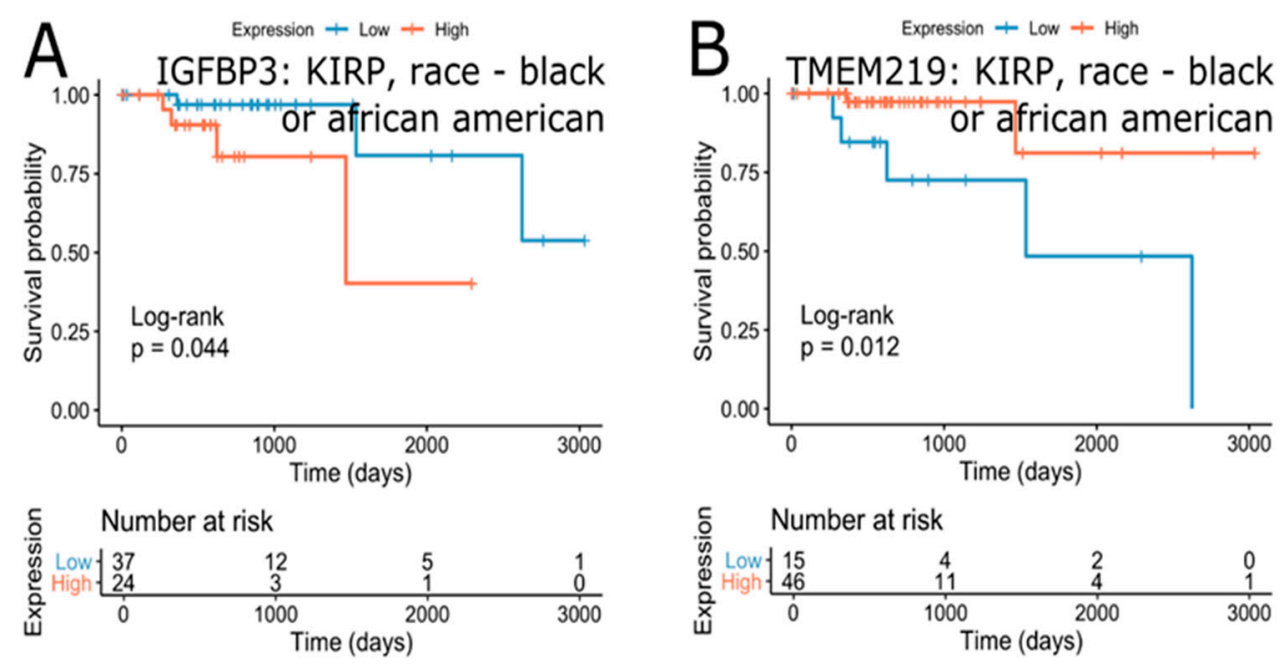

Figure 9. Survival effect of IGFBP3 (A) and TMEM219 (B) in "race-black or African-American." Kidney renal papillary cell carcinoma. Unadjusted $\mathrm{p}$-values are shown.

\subsection{Survival Effect of IGFBP-3 and TMEM219 in Breast Cancer}

Since the expression of IGFBP-3 and TMEM219 was not significantly associated with survival outcome in breast cancer, it is possible that heterogeneity of the disease may prevent the detection of significant associations. Consequent analysis of the survival effect of IGFBP-3 and TMEM219 in clinical subgroups of the breast cancer cohort revealed that clinical subgroup annotated as "histological type-Infiltrating Lobular Carcinoma" show marginally significant association of IGFBP-3 $\left(\mathrm{FDR}=2.01 \cdot 10^{-1}(\mathrm{HR}=0.36)\right)$ and TMEM219 $\left(\left(3.96 \cdot 10^{-2}(\mathrm{HR}=0.25)\right)\right.$ with the survival outcome (Figure 10B,C). For both genes, high expression was associated with a better prognosis. These results suggest that targeting the IGFBP-3/TMEM219 system in patients diagnosed with infiltrating lobular carcinoma, which is the second most common type of breast cancer, may be beneficial. Other clinical subgroups of breast cancer patients included "breast_carcinoma_surgical_procedure_name-Modified Radical Mastectomy" (IGFBP-3, FDR $=1.26 \cdot 10^{-1}(\mathrm{HR}=0.44)$, Figure 10A), "lab_proc_her2_neu_immunohistochemistry_receptor_status-Equivocal" (TMEM219, FDR = $\left.3.27 \cdot 10^{-1}(\mathrm{HR}=3.29)\right)$. Of note were race-specific survival effects with high expression of IGFBP-3 being beneficial in the "race-black or African-American" subgroup (FDR = 2.01·10 ${ }^{-1}(\mathrm{HR}=0.42)$, Figure 10E) and TMEM219 high expression being beneficial in the "race-Asian" subgroup (FDR = $1.16 \cdot 10^{-1}(\mathrm{HR}=0.00)$, Figure 10D). Confirming our previous observations, the survival benefits of IGFBP-3 expression in breast cancer were consistently associated with high IGFBP-3 expression, while the effect of TMEM219 was more diverse and subgroup-specific. 

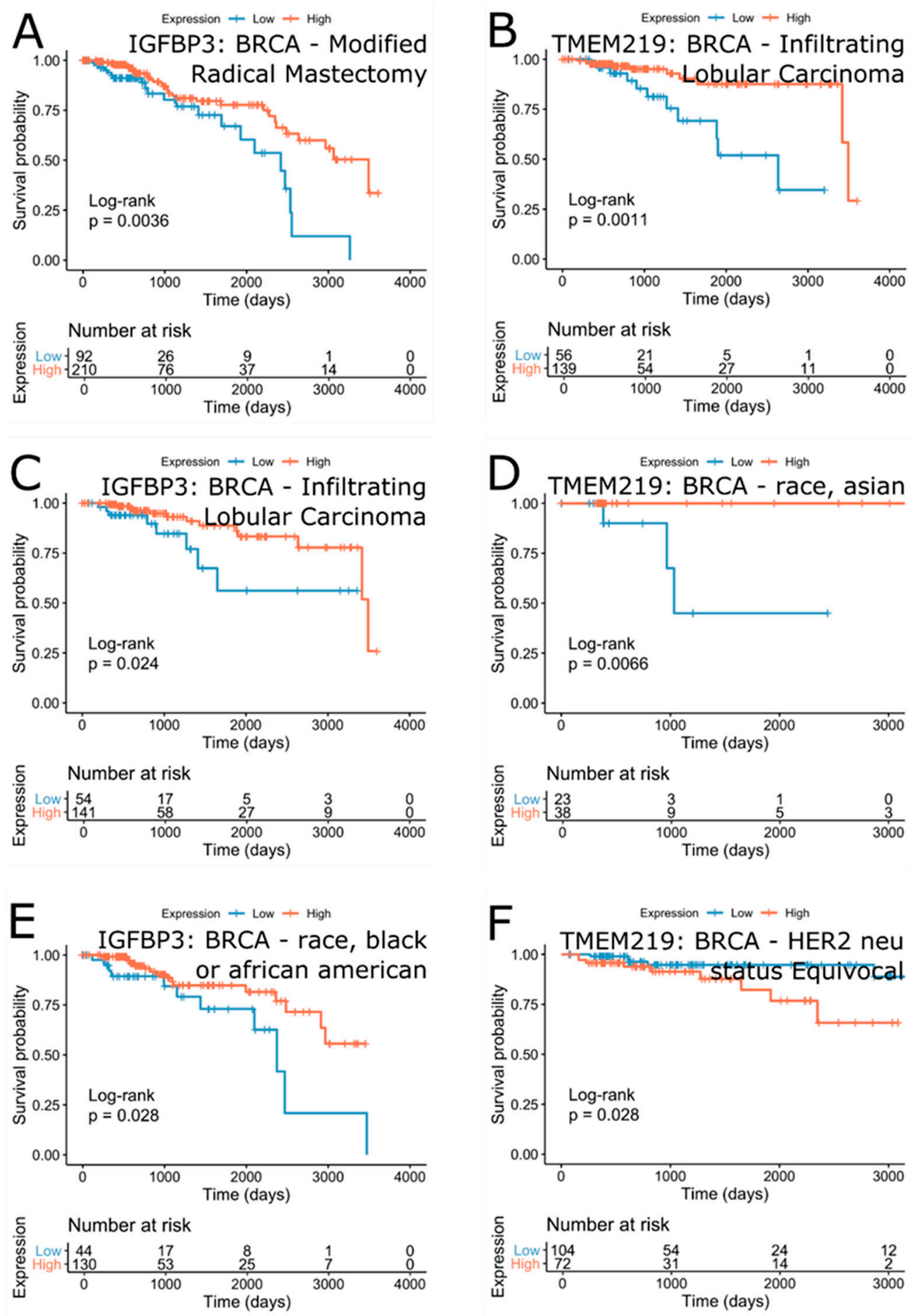

Figure 10. Survival effect of IGFBP-3 (A,C,E) and TMEM219 (B,D,F) in selected breast cancer subgroups. Unadjusted $p$-values are shown.

\section{Conclusions}

IGFBP-3 is a multifunctional protein and is involved in the pathophysiology of a variety of human diseases such as cancer, diabetes, fatty liver disease, ischemia, and Alzheimer's disease. Apart from the IGF/IGF-IR-dependent actions, IGFBP-3 exerts multiple biological activities through the IGF/IGF-IR-independent actions by interacting with distinct interacting proteins on the cell surface or within the cell. Much attention was given to identify a putative receptor for IGFBP-3 since early studies have demonstrated the anti-tumor function of IGFBP-3 in cancer. As described in this review, a few 
membrane proteins have been identified as "a putative IGFBP-3 receptor" and further characterized their functions with potential underlying mechanisms in cancer cells. Among them, TMEM219 appears to be the most critical IGFBP-3 receptor mediating anti-tumor and anti-metastatic activities of IGFBP-3. Given the fact that IGFBP-3/IGFBP-3R (TMEM219) axis is impaired and shown to have great impact on the survival outcome in specific cancers, IGFBP-3 and TMEM219 may serve as new diagnostic and prognostic biomarkers in specific cancers. Importantly, IGFBP-3R (TMEM219) agonists, in particular TMEM219 agonistic mAbs, are very attractive cancer therapeutics since these agonists would exhibit no other biological activities of IGFBP-3 induced by the interaction with other binding partners. Further characterization of specific gene regulation by TMEM219 activation and its crosstalk with other key signaling pathways will open a new avenue to treat many different types of cancer as a targeted monotherapy and a combination therapy with other chemotherapies.

Author Contributions: Writing, Q.C., M.D., and Y.O. Review and editing, M.D. and Y.O. All authors have read and agreed to the published version of the manuscript.

Funding: This work was supported, in part, by NIH-NCI Grant R21CA216685 (to Y.O).

Conflicts of Interest: The authors declare no conflicts of interest.

\section{References}

1. Wood, W.I.; Cachianes, G.; Henzel, W.J.; Winslow, G.A.; Spencer, S.A.; Hellmiss, R.; Martin, J.L.; Baxter, R.C. Cloning and expression of the growth hormone-dependent insulin-like growth factor-binding protein. Mol. Endocrinol. 1988, 2, 1176-1185. [CrossRef] [PubMed]

2. Hwa, V.; Oh, Y.; Rosenfeld, R.G. The insulin-like growth factor-binding protein (IGFBP) superfamily. Endocr. Rev. 1999, 20, 761-787. [CrossRef] [PubMed]

3. Jogie-Brahim, S.; Feldman, D.; Oh, Y. Unraveling insulin-like growth factor binding protein-3 actions in human disease. Endocr. Rev. 2009, 30, 417-437. [CrossRef] [PubMed]

4. Yamada, P.M.; Lee, K.W. Perspectives in mammalian IGFBP-3 biology: Local vs. systemic action. Am. J. Physiol. Cell Physiol. 2009, 296, C954-C976. [CrossRef]

5. Baxter, R.C. IGF binding proteins in cancer: Mechanistic and clinical insights. Nat. Rev. Cancer 2014, 14, 329-341. [CrossRef]

6. Johnson, M.A.; Firth, S.M. IGFBP-3: A cell fate pivot in cancer and disease. Growth Horm. IGF Res. 2014, 24, 164-173. [CrossRef]

7. Buckway, C.K.; Wilson, E.M.; Ahlsen, M.; Bang, P.; Oh, Y.; Rosenfeld, R.G. Mutation of three critical amino acids of the N-terminal domain of IGF-binding protein-3 essential for high affinity IGF binding. J. Clin. Endocrinol. Metab. 2001, 86, 4943-4950. [CrossRef]

8. Firth, S.M.; Baxter, R.C. Characterisation of recombinant glycosylation variants of insulin-like growth factor binding protein-3. J. Endocrinol. 1999, 160, 379-387. [CrossRef]

9. Hoeck, W.G.; Mukku, V.R. Identification of the major sites of phosphorylation in IGF binding protein-3. J. Cell Biochem. 1994, 56, 262-273. [CrossRef]

10. Bang, P.; Fielder, P.J. Human pregnancy serum contains at least two distinct proteolytic activities with the ability to degrade insulin-like growth factor binding protein-3. Endocrinology 1997, 138, 3912-3917. [CrossRef]

11. Firth, S.M.; Baxter, R.C. Cellular actions of the insulin-like growth factor binding proteins. Endocr. Rev. 2002, 23, 824-854. [CrossRef]

12. Schedlich, L.J;; Nilsen, T.; John, A.P.; Jans, D.A.; Baxter, R.C. Phosphorylation of insulin-like growth factor binding protein-3 by deoxyribonucleic acid-dependent protein kinase reduces ligand binding and enhances nuclear accumulation. Endocrinology 2003, 144, 1984-1993. [CrossRef] [PubMed]

13. Cobb, L.J.; Liu, B.; Lee, K.W.; Cohen, P. Phosphorylation by DNA-dependent protein kinase is critical for apoptosis induction by insulin-like growth factor binding protein-3. Cancer Res. 2006, 66, 10878-10884. [CrossRef] [PubMed]

14. Fowlkes, J.L.; Thrailkill, K.M.; Serra, D.M.; Suzuki, K.; Nagase, H. Matrix metalloproteinases as insulin-like growth factor binding protein-degrading proteinases. Prog. Growth Factor Res. 1995, 6, 255-263. [CrossRef] 
15. Ingermann, A.R.; Yang, Y.F.; Han, J.; Mikami, A.; Garza, A.E.; Mohanraj, L.; Fan, L.; Idowu, M.; Ware, J.L.; Kim, H.S.; et al. Identification of a novel cell death receptor mediating IGFBP-3-induced anti-tumor effects in breast and prostate cancer. J. Biol. Chem. 2010, 285, 30233-30246. [CrossRef] [PubMed]

16. Spencer, E.M.; Chan, K. A 3-dimensional model for the insulin-like growth factor binding proteins (IGFBPs); supporting evidence using the structural determinants of the IGF binding site on IGFBP-3. Prog. Growth Factor Res. 1995, 6, 209-214. [CrossRef]

17. Ho, P.J.; Baxter, R.C. Characterization of truncated insulin-like growth factor-binding protein-2 in human milk. Endocrinology 1997, 138, 3811-3818. [CrossRef]

18. Devi, G.R.; Yang, D.H.; Rosenfeld, R.G.; Oh, Y. Differential effects of insulin-like growth factor (IGF)-binding protein-3 and its proteolytic fragments on ligand binding, cell surface association, and IGF-I receptor signaling. Endocrinology 2000, 141, 4171-4179. [CrossRef]

19. Galanis, M.; Firth, S.M.; Bond, J.; Nathanielsz, A.; Kortt, A.A.; Hudson, P.J.; Baxter, R.C. Ligand-binding characteristics of recombinant amino- and carboxyl-terminal fragments of human insulin-like growth factor-binding protein-3. J. Endocrinol. 2001, 169, 123-133. [CrossRef]

20. Fowlkes, J.L.; Serra, D.M. Characterization of glycosaminoglycan-binding domains present in insulin-like growth factor-binding protein-3. J. Biol. Chem. 1996, 271, 14676-14679. [CrossRef]

21. Smith, E.P.; Lu, L.; Chernausek, S.D.; Klein, D.J. Insulin-like growth factor-binding protein-3 (IGFBP-3) concentration in rat Sertoli cell-conditioned medium is regulated by a pathway involving association of IGFBP-3 with cell surface proteoglycans. Endocrinology 1994, 135, 359-364. [CrossRef] [PubMed]

22. Campbell, P.G.; Durham, S.K.; Hayes, J.D.; Suwanichkul, A.; Powell, D.R. Insulin-like growth factor-binding protein-3 binds fibrinogen and fibrin. J. Biol. Chem. 1999, 274, 30215-30221. [CrossRef] [PubMed]

23. Baxter, R.C.; Martin, J.L.; Beniac, V.A. High molecular weight insulin-like growth factor binding protein complex. Purification and properties of the acid-labile subunit from human serum. J. Biol. Chem. 1989, 264, 11843-11848. [PubMed]

24. Huq, A.; Singh, B.; Meeker, T.; Mascarenhas, D. The metal-binding domain of IGFBP-3 selectively delivers therapeutic molecules into cancer cells. Anticancer Drugs 2009, 20, 21-31. [CrossRef]

25. Schedlich, L.J.; Le Page, S.L.; Firth, S.M.; Briggs, L.J.; Jans, D.A.; Baxter, R.C. Nuclear import of insulin-like growth factor-binding protein-3 and -5 is mediated by the importin beta subunit. J. Biol. Chem. 2000, 275, 23462-23470. [CrossRef]

26. Lee, K.W.; Liu, B.; Ma, L.; Li, H.; Bang, P.; Koeffler, H.P.; Cohen, P. Cellular internalization of insulin-like growth factor binding protein-3: Distinct endocytic pathways facilitate re-uptake and nuclear localization. J. Biol. Chem. 2004, 279, 469-476. [CrossRef]

27. Mohan, S.; Baylink, D.J.; Pettis, J.L. Insulin-like growth factor (IGF)-binding proteins in serum-do they have additional roles besides modulating the endocrine IGF actions? J. Clin. Endocrinol. Metab. 1996, 81, 3817-3820. [CrossRef]

28. Rajaram, S.; Baylink, D.J.; Mohan, S. Insulin-like growth factor-binding proteins in serum and other biological fluids: Regulation and functions. Endocr. Rev. 1997, 18, 801-831.

29. Clemmons, D.R. Role of insulin-like growth factor binding proteins in controlling IGF actions. Mol. Cell Endocrinol. 1998, 140, 19-24. [CrossRef]

30. Kelley, K.M.; Oh, Y.; Gargosky, S.E.; Gucev, Z.; Matsumoto, T.; Hwa, V.; Ng, L.; Simpson, D.M.; Rosenfeld, R.G. Insulin-like growth factor-binding proteins (IGFBPs) and their regulatory dynamics. Int. J. Biochem. Cell Biol. 1996, 28, 619-637. [CrossRef]

31. Ferry, R.J., Jr.; Cerri, R.W.; Cohen, P. Insulin-like growth factor binding proteins: New proteins, new functions. Horm. Res. 1999, 51, 53-67. [CrossRef] [PubMed]

32. Collett-Solberg, P.F.; Cohen, P. Genetics, chemistry, and function of the IGF/IGFBP system. Endocrine 2000, 12, 121-136. [CrossRef]

33. Oh, Y.; Muller, H.L.; Lamson, G.; Rosenfeld, R.G. Insulin-like growth factor (IGF)-independent action of IGF-binding protein-3 in Hs578T human breast cancer cells. Cell surface binding and growth inhibition. J. Biol. Chem. 1993, 268, 14964-14971. [PubMed]

34. Rajah, R.; Valentinis, B.; Cohen, P. Insulin-like growth factor (IGF)-binding protein-3 induces apoptosis and mediates the effects of transforming growth factor-beta1 on programmed cell death through a p53-and IGF-independent mechanism. J. Biol. Chem. 1997, 272, 12181-12188. [CrossRef] [PubMed] 
35. Leal, S.M.; Huang, S.S.; Huang, J.S. Interactions of high affinity insulin-like growth factor-binding proteins with the type V transforming growth factor-beta receptor in mink lung epithelial cells. J. Biol. Chem. 1999, 274, 6711-6717. [CrossRef]

36. Wu, H.B.; Kumar, A.; Tsai, W.C.; Mascarenhas, D.; Healey, J.; Rechler, M.M. Characterization of the inhibition of DNA synthesis in proliferating mink lung epithelial cells by insulin-like growth factor binding protein-3. J. Cell Biochem. 2000, 77, 288-297. [CrossRef]

37. Ikonen, M.; Liu, B.; Hashimoto, Y.; Ma, L.; Lee, K.W.; Niikura, T.; Nishimoto, I.; Cohen, P. Interaction between the Alzheimer's survival peptide humanin and insulin-like growth factor-binding protein 3 regulates cell survival and apoptosis. Proc. Natl. Acad. Sci. USA 2003, 100, 13042-13047. [CrossRef]

38. Chen, X.; Ferry, R.J., Jr. Novel actions of IGFBP-3 on intracellular signaling pathways of insulin-secreting cells. Growth Horm. IGF Res. 2006, 16, 41-48. [CrossRef]

39. Chang, K.H.; Chan-Ling, T.; McFarland, E.L.; Afzal, A.; Pan, H.; Baxter, L.C.; Shaw, L.C.; Caballero, S.; Sengupta, N.; Li Calzi, S.; et al. IGF binding protein-3 regulates hematopoietic stem cell and endothelial precursor cell function during vascular development. Proc. Natl. Acad. Sci. USA 2007, 104, 10595-10600. [CrossRef]

40. Grimberg, A.; Coleman, C.M.; Burns, T.F.; Himelstein, B.P.; Koch, C.J.; Cohen, P.; El-Deiry, W.S. p53-Dependent and p53-independent induction of insulin-like growth factor binding protein-3 by deoxyribonucleic acid damage and hypoxia. J. Clin. Endocrinol. Metab. 2005, 90, 3568-3574. [CrossRef]

41. Lofqvist, C.; Chen, J.; Connor, K.M.; Smith, A.C.; Aderman, C.M.; Liu, N.; Pintar, J.E.; Ludwig, T.; Hellstrom, A.; Smith, L.E. IGFBP3 suppresses retinopathy through suppression of oxygen-induced vessel loss and promotion of vascular regrowth. Proc. Natl. Acad. Sci. USA 2007, 104, 10589-10594. [CrossRef] [PubMed]

42. Williams, A.C.; Smartt, H.; H-Zadeh, A.; MMacfarlane, M.; Paraskeva, C.; Collard, T.J. Insulin-like growth factor binding protein 3 (IGFBP-3) potentiates TRAIL-induced apoptosis of human colorectal carcinoma cells through inhibition of NF-kappaB. Cell Death Differ. 2007, 14, 137-145. [CrossRef]

43. Mehta, H.H.; Gao, Q.; Galet, C.; Paharkova, V.; Wan, J.; Said, J.; Sohn, J.J.; Lawson, G.; Cohen, P.; Cobb, L.J.; et al. IGFBP-3 is a metastasis suppression gene in prostate cancer. Cancer Res. 2011, 71, 5154-5163. [CrossRef] [PubMed]

44. Mohanraj, L.; Kim, H.S.; Li, W.; Cai, Q.; Kim, K.E.; Shin, H.J.; Lee, Y.J.; Lee, W.J.; Kim, J.H.; Oh, Y. IGFBP-3 inhibits cytokine-induced insulin resistance and early manifestations of atherosclerosis. PLoS ONE 2013, 8, e55084. [CrossRef] [PubMed]

45. Min, H.K.; Maruyama, H.; Jang, B.K.; Shimada, M.; Mirshahi, F.; Ren, S.; Oh, Y.; Puri, P.; Sanyal, A.J. Suppression of IGF binding protein-3 by palmitate promotes hepatic inflammatory responses. FASEB J. 2016, 30, 4071-4082. [CrossRef] [PubMed]

46. Kim, M.; Cai, Q.; Oh, Y. Therapeutic potential of alpha-1 antitrypsin in human disease. Ann. Pediatr. Endocrinol. Metab. 2018, 23, 131-135. [CrossRef]

47. Arab, J.P.; Cabrera, D.; Sehrawat, T.S.; Jalan-Sakrikar, N.; Verma, V.K.; Simonetto, D.; Cao, S.; Yaqoob, U.; Leon, J.; Freire, M.; et al. Hepatic stellate cell activation promotes alcohol-induced steatohepatitis through Igfbp3 and SerpinA12. J. Hepatol. 2020. [CrossRef]

48. Gucev, Z.S.; Oh, Y.; Kelley, K.M.; Rosenfeld, R.G. Insulin-like growth factor binding protein 3 mediates retinoic acid-and transforming growth factor beta2-induced growth inhibition in human breast cancer cells. Cancer Res. 1996, 56, 1545-1550.

49. Hembree, J.R.; Agarwal, C.; Beard, R.L.; Chandraratna, R.A.; Eckert, R. Retinoid X receptor-specific retinoids inhibit the ability of retinoic acid receptor-specific retinoids to increase the level of insulin-like growth factor binding protein-3 in human ectocervical epithelial cells. Cancer Res. 1996, 56, 1794-1799.

50. Rozen, F.; Zhang, J.; Pollak, M. Antiproliferative action of tumor necrosis factor-alpha on MCF-7 breastcancer cells is associated with increased insulin-like growth factor binding protein-3 accumulation. Int. J. Oncol. 1998, 13, 865-869. [CrossRef]

51. Colston, K.W.; Perks, C.M.; Xie, S.P.; Holly, J.M. Growth inhibition of both MCF-7 and Hs578T human breast cancer cell lines by vitamin D analogues is associated with increased expression of insulin-like growth factor binding protein-3. J. Mol. Endocrinol. 1998, 20, 157-162. [CrossRef] [PubMed]

52. Huynh, H.; Yang, X.; Pollak, M. Estradiol and antiestrogens regulate a growth inhibitory insulin-like growth factor binding protein 3 autocrine loop in human breast cancer cells. J. Biol. Chem. 1996, 271, 1016-1021. [CrossRef] [PubMed] 
53. Martin, J.L.; Baxter, R.C. Transforming growth factor-beta stimulates production of insulin-like growth factor-binding protein-3 by human skin fibroblasts. Endocrinology 1991, 128, 1425-1433. [CrossRef] [PubMed]

54. Oh, Y.; Muller, H.L.; Ng, L.; Rosenfeld, R.G. Transforming growth factor-beta-induced cell growth inhibition in human breast cancer cells is mediated through insulin-like growth factor-binding protein-3 action. J. Biol. Chem. 1995, 270, 13589-13592. [CrossRef] [PubMed]

55. Zhou, W.; Wang, S.; Ying, Y.; Zhou, R.; Mao, P. miR-196b/miR-1290 participate in the antitumor effect of resveratrol via regulation of IGFBP3 expression in acute lymphoblastic leukemia. Oncol. Rep. 2017, 37, 1075-1083. [CrossRef] [PubMed]

56. Xia, Y.; Jin, L.; Zhang, B.; Xue, H.; Li, Q.; Xu, Y. The potentiation of curcumin on insulin-like growth factor-1 action in MCF-7 human breast carcinoma cells. Life Sci. 2007, 80, 2161-2169. [CrossRef] [PubMed]

57. Vijayababu, M.R.; Arunkumar, A.; Kanagaraj, P.; Arunakaran, J. Effects of quercetin on insulin-like growth factors (IGFs) and their binding protein-3 (IGFBP-3) secretion and induction of apoptosis in human prostate cancer cells. J. Carcinog. 2006, 5, 10. [CrossRef]

58. Buckbinder, L.; Talbott, R.; Velasco-Miguel, S.; Takenaka, I.; Faha, B.; Seizinger, B.R.; Kley, N. Induction of the growth inhibitor IGF-binding protein 3 by p53. Nature 1995, 377, 646-649. [CrossRef]

59. Bourdon, J.C.; Deguin-Chambon, V.; Lelong, J.C.; Dessen, P.; May, P.; Debuire, B.; May, E. Further characterisation of the $\mathrm{p} 53$ responsive element-identification of new candidate genes for trans-activation by p53. Oncogene 1997, 14, 85-94. [CrossRef]

60. Ludwig, R.L.; Bates, S.; Vousden, K.H. Differential activation of target cellular promoters by p53 mutants with impaired apoptotic function. Mol. Cell Biol. 1996, 16, 4952-4960. [CrossRef]

61. Barbieri, C.E.; Perez, C.A.; Johnson, K.N.; Ely, K.A.; Billheimer, D.; Pietenpol, J.A. IGFBP-3 is a direct target of transcriptional regulation by DeltaNp63alpha in squamous epithelium. Cancer Res. 2005, 65, 2314-2320. [CrossRef] [PubMed]

62. Chang, Y.S.; Wang, L.; Liu, D.; Mao, L.; Hong, W.K.; Khuri, F.R.; Lee, H.Y. Correlation between insulin-like growth factor-binding protein-3 promoter methylation and prognosis of patients with stage I non-small cell lung cancer. Clin. Cancer Res. 2002, 8, 3669-3675. [PubMed]

63. Wiley, A.; Katsaros, D.; Fracchioli, S.; Yu, H. Methylation of the insulin-like growth factor binding protein-3 gene and prognosis of epithelial ovarian cancer. Int. J. Gynecol. Cancer 2006, 16, 210-218. [CrossRef] [PubMed]

64. Ibanez de Caceres, I.; Cortes-Sempere, M.; Moratilla, C.; Machado-Pinilla, R.; Rodriguez-Fanjul, V.; Manguan-Garcia, C.; Cejas, P.; Lopez-Rios, F.; Paz-Ares, L.; de CastroCarpeno, J.; et al. IGFBP-3 hypermethylation-derived deficiency mediates cisplatin resistance in non-small-cell lung cancer. Oncogene 2010, 29, 1681-1690. [CrossRef] [PubMed]

65. Harada, A.; Jogie-Brahim, S.; Oh, Y. Tobacco specific carcinogen 4-(methylnitrosamino)-1-(3-pyridyl)-1butanone suppresses a newly identified anti-tumor IGFBP-3/IGFBP-3R system in lung cancer cells. Lung Cancer 2013, 80, 270-277. [CrossRef] [PubMed]

66. Perez-Carbonell, L.; Balaguer, F.; Toiyama, Y.; Egoavil, C.; Rojas, E.; Guarinos, C.; Andreu, M.; Llor, X.; Castells, A.; Jover, R.; et al. IGFBP3 methylation is a novel diagnostic and predictive biomarker in colorectal cancer. PLoS ONE 2014, 9, e104285. [CrossRef] [PubMed]

67. Pernia, O.; Belda-Iniesta, C.; Pulido, V.; Cortes-Sempere, M.; Rodriguez, C.; Vera, O.; Soto, J.; Jimenez, J.; Taus, A.; Rojo, F.; et al. Methylation status of IGFBP-3 as a useful clinical tool for deciding on a concomitant radiotherapy. Epigenetics 2014, 9, 1446-1453. [CrossRef] [PubMed]

68. Perks, C.M.; Holly, J.M. Epigenetic regulation of insulin-like growth factor binding protein-3 (IGFBP-3) in cancer. J. Cell Commun. Signal 2015, 9, 159-166. [CrossRef]

69. Fu, T.; Pappou, E.P.; Guzzetta, A.A.; Calmon Mde, F.; Sun, L.; Herrera, A.; Li, F.; Wolfgang, C.L.; Baylin, S.B.; Iacobuzio-Donahue, C.A.; et al. IGFBP-3 Gene Methylation in Primary Tumor Predicts Recurrence of Stage II Colorectal Cancers. Ann. Surg. 2016, 263, 337-344. [CrossRef] [PubMed]

70. Oh, Y.; Muller, H.L.; Pham, H.; Rosenfeld, R.G. Demonstration of receptors for insulin-like growth factor binding protein-3 on Hs578T human breast cancer cells. J. Biol. Chem. 1993, 268, 26045-26048.

71. Huang, S.S.; Ling, T.Y.; Tseng, W.F.; Huang, Y.H.; Tang, F.M.; Leal, S.M.; Huang, J.S. Cellular growth inhibition by IGFBP-3 and TGF-beta1 requires LRP-1. FASEB J. 2003, 17, 2068-2081. [CrossRef] [PubMed] 
72. Mishra, S.; Raz, A.; Murphy, L.J. Insulin-like growth factor binding protein-3 interacts with autocrine motility factor/phosphoglucose isomerase (AMF/PGI) and inhibits the AMF/PGI function. Cancer Res. 2004, 64, 2516-2522. [CrossRef] [PubMed]

73. Weinzimer, S.A.; Gibson, T.B.; Collett-Solberg, P.F.; Khare, A.; Liu, B.; Cohen, P. Transferrin is an insulin-like growth factor-binding protein-3 binding protein. J. Clin. Endocrinol. Metab. 2001, 86, 1806-1813. [CrossRef] [PubMed]

74. Leal, S.M.; Liu, Q.; Huang, S.S.; Huang, J.S. The type V transforming growth factor beta receptor is the putative insulin-like growth factor-binding protein 3 receptor. J. Biol. Chem. 1997, 272, 20572-20576. [CrossRef]

75. Huang, S.S.; Leal, S.M.; Chen, C.L.; Liu, I.H.; Huang, J.S. Identification of insulin receptor substrate proteins as key molecules for the TbetaR-V/LRP-1-mediated growth inhibitory signaling cascade in epithelial and myeloid cells. FASEB J. 2004, 18, 1719-1721. [CrossRef]

76. Lee, S.H.; Takahashi, M.; Honke, K.; Miyoshi, E.; Osumi, D.; Sakiyama, H.; Ekuni, A.; Wang, X.; Inoue, S.; $\mathrm{Gu}, \mathrm{J}$; et al. Loss of core fucosylation of low-density lipoprotein receptor-related protein-1 impairs its function, leading to the upregulation of serum levels of insulin-like growth factor-binding protein 3 in Fut8-/-mice. J. Biochem. 2006, 139, 391-398. [CrossRef]

77. Mangasser-Stephan, K.; Gressner, A.M. Molecular and functional aspects of latent transforming growth factor-beta binding protein: Just a masking protein? Cell Tissue Res. 1999, 297, 363-370. [CrossRef]

78. Gui, Y.; Murphy, L.J. Interaction of insulin-like growth factor binding protein-3 with latent transforming growth factor-beta binding protein-1. Mol. Cell Biochem. 2003, 250, 189-195. [CrossRef]

79. Rifkin, D.B. Latent transforming growth factor-beta (TGF-beta) binding proteins: Orchestrators of TGF-beta availability. J. Biol. Chem. 2005, 280, 7409-7412. [CrossRef]

80. Nwosu, Z.C.; Ebert, M.P.; Dooley, S.; Meyer, C. Caveolin-1 in the regulation of cell metabolism: A cancer perspective. Mol. Cancer 2016, 15, 71. [CrossRef]

81. Oufattole, M.; Lin, S.W.; Liu, B.; Mascarenhas, D.; Cohen, P.; Rodgers, B.D. Ribonucleic acid polymerase II binding subunit 3 (Rpb3), a potential nuclear target of insulin-like growth factor binding protein-3. Endocrinology 2006, 147, 2138-2146. [CrossRef] [PubMed]

82. Wu, C.; Yao, G.; Zou, M.; Chen, G.; Wang, M.; Liu, J.; Wang, J.; Xu, D. N-Acetylgalactosaminyltransferase 14, a novel insulin-like growth factor binding protein-3 binding partner. Biochem. Biophys. Res. Commun. 2007, 357, 360-365. [CrossRef] [PubMed]

83. Li, C.; Harada, A.; Oh, Y. IGFBP-3 sensitizes antiestrogen-resistant breast cancer cells through interaction with GRP78. Cancer Lett. 2012, 325, 200-206. [CrossRef] [PubMed]

84. Grkovic, S.; O’Reilly, V.C.; Han, S.; Hong, M.; Baxter, R.C.; Firth, S.M. IGFBP-3 binds GRP78, stimulates autophagy and promotes the survival of breast cancer cells exposed to adverse microenvironments. Oncogene 2013, 32, 2412-2420. [CrossRef]

85. Liu, B.; Lee, H.Y.; Weinzimer, S.A.; Powell, D.R.; Clifford, J.L.; Kurie, J.M.; Cohen, P. Direct functional interactions between insulin-like growth factor-binding protein-3 and retinoid $\mathrm{X}$ receptor-alpha regulate transcriptional signaling and apoptosis. J. Biol. Chem. 2000, 275, 33607-33613. [CrossRef] [PubMed]

86. Schedlich, L.J.; O'Han, M.K.; Leong, G.M.; Baxter, R.C. Insulin-like growth factor binding protein-3 prevents retinoid receptor heterodimerization: Implications for retinoic acid-sensitivity in human breast cancer cells. Biochem. Biophys. Res. Commun. 2004, 314, 83-88. [CrossRef]

87. Lee, K.W.; Cobb, L.J.; Paharkova-Vatchkova, V.; Liu, B.; Milbrandt, J.; Cohen, P. Contribution of the orphan nuclear receptor Nur77 to the apoptotic action of IGFBP-3. Carcinogenesis 2007, 28, 1653-1658. [CrossRef]

88. Moreno-Santos, I.; Castellano-Castillo, D.; Lara, M.F.; Fernandez-Garcia, J.C.; Tinahones, F.J.; Macias-Gonzalez, M. IGFBP-3 Interacts with the Vitamin D Receptor in Insulin Signaling Associated with Obesity in Visceral Adipose Tissue. Int. J. Mol. Sci. 2017, 18, 2349. [CrossRef]

89. Chan, S.S.; Schedlich, L.J.; Twigg, S.M.; Baxter, R.C. Inhibition of adipocyte differentiation by insulin-like growth factor-binding protein-3. Am. J. Physiol. Endocrinol. Metab. 2009, 296, E654-E663. [CrossRef]

90. Njomen, E.; Evans, H.G.; Gedara, S.H.; Heyl, D.L. Humanin Peptide Binds to Insulin-Like Growth Factor-Binding Protein 3 (IGFBP3) and Regulates Its Interaction with Importin-beta. Protein. Pept. Lett. 2015, 22, 869-876. [CrossRef]

91. Wang, H.; Tachibana, K.; Zhang, Y.; Iwasaki, H.; Kameyama, A.; Cheng, L.; Guo, J.; Hiruma, T.; Togayachi, A.; Kudo, T.; et al. Cloning and characterization of a novel UDP-GalNAc:polypeptide 
N-acetylgalactosaminyltransferase, pp-GalNAc-T14. Biochem. Biophys. Res. Commun. 2003, 300, 738-744. [CrossRef]

92. Kwon, O.S.; Oh, E.; Park, J.R.; Lee, J.S.; Bae, G.Y.; Koo, J.H.; Kim, H.; Choi, Y.L.; Choi, Y.S.; Kim, J.; et al. GalNAc-T14 promotes metastasis through Wnt dependent HOXB9 expression in lung adenocarcinoma. Oncotarget 2015, 6, 41916-41928. [CrossRef]

93. Yang, J.; Hu, Y.; Wu, J.; Kong, S. Effects of IGFBP-3 and GalNAc-T14 on proliferation and cell cycle of glioblastoma cells and its mechanism. J. Pharm. Pharmacol. 2020, 72, 218-226. [CrossRef] [PubMed]

94. Li, J.; Ni, M.; Lee, B.; Barron, E.; Hinton, D.R.; Lee, A.S. The unfolded protein response regulator GRP78/BiP is required for endoplasmic reticulum integrity and stress-induced autophagy in mammalian cells. Cell Death Differ. 2008, 15, 1460-1471. [CrossRef] [PubMed]

95. Bertolotti, A.; Zhang, Y.; Hendershot, L.M.; Harding, H.P.; Ron, D. Dynamic interaction of BiP and ER stress transducers in the unfolded-protein response. Nat. Cell Biol. 2000, 2, 326-332. [CrossRef]

96. Wang, M.; Wey, S.; Zhang, Y.; Ye, R.; Lee, A.S. Role of the unfolded protein response regulator GRP78/BiP in development, cancer, and neurological disorders. Antioxid. Redox. Signal 2009, 11, 2307-2316. [CrossRef] [PubMed]

97. Jing, G.; Wang, J.J.; Zhang, S.X. ER stress and apoptosis: A new mechanism for retinal cell death. Exp. Diabetes Res. 2012, 2012, 589589. [CrossRef]

98. Lee, K.W.; Ma, L.; Yan, X.; Liu, B.; Zhang, X.K.; Cohen, P. Rapid apoptosis induction by IGFBP-3 involves an insulin-like growth factor-independent nucleomitochondrial translocation of RXRalpha/Nur77. J. Biol. Chem. 2005, 280, 16942-16948. [CrossRef]

99. Kastner, P.; Mark, M.; Chambon, P. Nonsteroid nuclear receptors: What are genetic studies telling us about their role in real life? Cell 1995, 83, 859-869. [CrossRef]

100. Mangelsdorf, D.J.; Evans, R.M. The RXR heterodimers and orphan receptors. Cell 1995, 83, 841-850. [CrossRef]

101. Germain, P.; Staels, B.; Dacquet, C.; Spedding, M.; Laudet, V. Overview of nomenclature of nuclear receptors. Pharmacol. Rev. 2006, 58, 685-704. [CrossRef] [PubMed]

102. Hazel, T.G.; Nathans, D.; Lau, L.F. A gene inducible by serum growth factors encodes a member of the steroid and thyroid hormone receptor superfamily. Proc. Natl. Acad. Sci. USA 1988, 85, 8444-8448. [CrossRef] [PubMed]

103. Bhattacharyya, N.; Pechhold, K.; Shahjee, H.; Zappala, G.; Elbi, C.; Raaka, B.; Wiench, M.; Hong, J.; Rechler, M.M. Nonsecreted insulin-like growth factor binding protein-3 (IGFBP-3) can induce apoptosis in human prostate cancer cells by IGF-independent mechanisms without being concentrated in the nucleus. J. Biol. Chem. 2006, 281, 24588-24601. [CrossRef] [PubMed]

104. Zappala, G.; Elbi, C.; Edwards, J.; Gorenstein, J.; Rechler, M.M.; Bhattacharyya, N. Induction of apoptosis in human prostate cancer cells by insulin-like growth factor binding protein-3 does not require binding to retinoid X receptor-alpha. Endocrinology 2008, 149, 1802-1812. [CrossRef] [PubMed]

105. Yamanaka, Y.; Fowlkes, J.L.; Wilson, E.M.; Rosenfeld, R.G.; Oh, Y. Characterization of insulin-like growth factor binding protein-3 (IGFBP-3) binding to human breast cancer cells: Kinetics of IGFBP-3 binding and identification of receptor binding domain on the IGFBP-3 molecule. Endocrinology 1999, 140, 1319-1328. [CrossRef]

106. Ruan, W.; Becker, V.; Klingmuller, U.; Langosch, D. The interface between self-assembling erythropoietin receptor transmembrane segments corresponds to a membrane-spanning leucine zipper. J. Biol. Chem. 2004, 279, 3273-3279. [CrossRef]

107. Noordeen, N.A.; Carafoli, F.; Hohenester, E.; Horton, M.A.; Leitinger, B. A transmembrane leucine zipper is required for activation of the dimeric receptor tyrosine kinase DDR1. J. Biol. Chem. 2006, 281, 22744-22751. [CrossRef]

108. Ding, H.F.; Lin, Y.L.; McGill, G.; Juo, P.; Zhu, H.; Blenis, J.; Yuan, J.; Fisher, D.E. Essential role for caspase-8 in transcription-independent apoptosis triggered by p53. J. Biol. Chem. 2000, 275, 38905-38911. [CrossRef]

109. Zhao, H.; Ross, F.P.; Teitelbaum, S.L. Unoccupied alpha(v)beta3 integrin regulates osteoclast apoptosis by transmitting a positive death signal. Mol. Endocrinol. 2005, 19, 771-780. [CrossRef]

110. Baxter, R.C.; Martin, J.L. Structure of the Mr 140,000 growth hormone-dependent insulin-like growth factor binding protein complex: Determination by reconstitution and affinity-labeling. Proc. Natl. Acad. Sci. USA 1989, 86, 6898-6902. [CrossRef] 
111. Han, J.; Jogie-Brahim, S.; Harada, A.; Oh, Y. Insulin-like growth factor-binding protein-3 suppresses tumor growth via activation of caspase-dependent apoptosis and cross-talk with NF-kappaB signaling. Cancer Lett. 2011, 307, 200-210. [CrossRef] [PubMed]

112. Oh, Y. Treatment of Diseases Related to IGFBP-3 and Its Receptor. International Application Number No. PCT/US2017/059244, International Publication Number WO/2018/085252, 11 May 2018.

113. Zhang, X.D.; Nguyen, T.; Thomas, W.D.; Sanders, J.E.; Hersey, P. Mechanisms of resistance of normal cells to TRAIL induced apoptosis vary between different cell types. FEBS Lett. 2000, 482, 193-199. [CrossRef]

114. Wagner, K.W.; Punnoose, E.A.; Januario, T.; Lawrence, D.A.; Pitti, R.M.; Lancaster, K.; Lee, D.; von Goetz, M.; Yee, S.F.; Totpal, K.; et al. Death-receptor O-glycosylation controls tumor-cell sensitivity to the proapoptotic ligand Apo2L/TRAIL. Nat. Med. 2007, 13, 1070-1077. [CrossRef] [PubMed]

115. Dubuisson, A.; Micheau, O. Antibodies and Derivatives Targeting DR4 and DR5 for Cancer Therapy. Antibodies 2017, 6, 16. [CrossRef] [PubMed]

116. Li, B.; Dewey, C. RSEM: Accurate transcript quantification from RNA-Seq data with or without a reference genome. BMC Bioinform. 2011, 12. [CrossRef] [PubMed]

117. R2: Genomics Analysis and Visualization Platform. Available online: http://r2.amc.nl (accessed on 12 May 2020).

118. Mihaly, Z.; Kormos, M.; Lanczky, A.; Dank, M.; Budczies, J.; Szasz, M.A.; Gyorffy, B. A meta-analysis of gene expression-based biomarkers predicting outcome after tamoxifen treatment in breast cancer. Breast Cancer Res. Treat. 2013, 140, 219-232. [CrossRef]

119. Benjamini, Y.; Hochberg, Y. Controlling the false discovery rate: A practical and powerful approach to multiple testing. J. R. Stat. Soc. Ser. B 1995, 289-300. [CrossRef]

(C) 2020 by the authors. Licensee MDPI, Basel, Switzerland. This article is an open access article distributed under the terms and conditions of the Creative Commons Attribution (CC BY) license (http://creativecommons.org/licenses/by/4.0/). 